\title{
The Principles of Effectiveness, Proportionality and Dissuasiveness in the Enforcement of EU Consumer Law: The Impact of a Triad on the Choice of Civil Remedies and Administrative Sanctions"
}

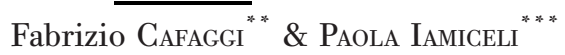

\begin{abstract}
In the conventional approach, rights were defined by EU law, while remedies were established by national legal orders. The situation has changed. The principle of procedural autonomy has been severely limited by general principles, such as the ones of effectiveness and equivalence. The power of Member States to define procedures, sanctions and remedies is strongly affected by the principles of effectiveness, proportionality and dissuasiveness.
\end{abstract}

This article will examine the principles of effectiveness, proportionality and dissuasiveness as a triad. The concept of triad is used both as an illustration and as an analytical tool. It is an illustration, since it reflects the frequent and contextual reference by EU secondary law to the three principles as distinct prescriptions to be complied with by the Member States. It is an analytical tool, since it enables the interpreter to look at diversities and complementarities within the triad as part of a coherent and harmonious system of rules.

The main purpose is to examine the impact of the triad in the judicial dialogue that emerges among national and EU courts addressing consumer law cases. More particularly, the analysis will focus on the configuration, the choice and the functioning of civil remedies in consumer law, analysing the case law arising in some of the Member States of the EU.

In the majority of cases, national legislators fail to provide legislative definitions of effectiveness, proportionality and dissuasiveness and implicitly 'delegate' the task of scrutinizing the legislative selection of remedies with the principles to the judiciary. The role of the judge and the strictness of the principles differ depending on whether the enforcement is criminal, administrative or civil. These differences require each enforcer to apply the principles in the context of multiple enforcement mechanisms, taking duly into account the effects that other enforcement mechanisms would produce.

* This article has been written within a wider research project on 'E.U. general principles for enforcement of rights and the role of E.U. and national courts'. Several judges and academics are contributing to the project and we are extremely grateful to all of them. In particular, we wish to thank for their generous commitment judges from the Association of European Administrative Judges (AEAJ), Federica Casarosa, Anna van Duin, Monika Jozon, Mateusz Grochowski, Chantal Mak, Madalina Bianca Moraru, Francesco Paolo Patti, Luca Perilli, Raffaele Sabato. The usual disclaimer applies. The final version of this article was handed in on 31 March 2017.

* Professor of Private and Comparative Law at the National School of administration and at the University of Trento, email: fabrizio.cafaggi@eui.eu

*** Professor of Private Law at the University of Trento, email: paola.iamiceli@unitn.it 
In the domain of private enforcement, the analysis below will show that, firstly, the judge plays (and shall play) an important function in setting the procedural conditions for an 'informed' remedial choice on the part of the consumer; this function tends to prevail over a more paternalistic role whereby the judge chooses the remedies on behalf of the consumer. Secondly, freedom of contract may still contribute to the definition of effective, proportionate and dissuasive remedies through contractual clauses or separate agreements to the extent that such clauses/agreements protect the consumer and do not reduce his or her power to choose.

The illustrations in the text suggest that references to the principles in national judicial applications are not extensive and that their definition is not consolidated. Institutional dialogue will play an important role to ensure that legislative choices are compliant with EU objectives and to fill gaps when legislators or regulators omit to offer proper guidance to national judges.

Key Words: Enforcement of consumer rights - Remedies - General principles Effectiveness, proportionality, dissuasiveness - Judicial dialogue

\section{Introduction}

1. The connecting link between rights and remedies has pervaded the western legal tradition for decades. ${ }^{1}$ The creation of rights has to be complemented with the provision of remedies. In the conventional approach, rights were defined by EU law, while remedies were established by national legal orders. The situation has changed. The principle of procedural autonomy has been severely reshaped by equivalence, effectiveness and proportionality. ${ }^{2}$

1 See W. van Gerven, 'Of Rights, Remedies and Procedures', CMLR (Common Market Law Review) 2000, p (500); D. Friedmann, 'Rights and Remedies', in N. Cohen \& E. McKendrick (eds), Comparative Remedies for Breach of Contract (Oxford: Hart Publishing 2005), p 3; J. BASEDOw, The Multiple Facets of Law Enforcement, Inaugural Lecture (Montevideo 2016), http://tc.iuscom paratum.info/tc/wp-content/uploads/2016/09/Basedow-Inaugural-Lecture.pdf.

2 See Art. 19.1 TFEU. See T. Tridimas, The General Principles of EU Law (Oxford: Oxford University Press 2006), p 419; N. ReIch, General Principles of EU Civil Law (Cambridge: Intersentia 2014), p 90 seq.; O.O. Cherednychenko, 'Public and Private Enforcement of European Private Law: Perspectives and Challenges', ERPL (European Review of Private Law) 2015(4), pp 481-490; C. MAK, Rights and Remedies - Article 47 EUCFR and Effective Judicial Protection in European Private Law Matters', in H.-W. Micklitz (ed.), Constitutionalization of European Private Law (Oxford: Oxford University Press 2014), p 236; H.-W. MicklitZ, 'The Transformation of Enforcement in European Private Law: Preliminary Considerations', ERPL (European Review of Private Law) 2015(4), p 517; A. CarratTA, 'Libertà fondamentali del Trattato UE e processo civile', in F. Mezzanotte (ed.), Le 'libertà fondamentali' dell'Unione europea e il diritto privato (Rome: Roma-Tre Press 2016), p 199 seq.; G. Vettori, 'The Fair Contract in the Constitutional System: Principles as an Imperative Content of Codified Rules in the Italian Case-Law', ERCL (European Review of Contract Law) 2016, pp (1-29) at 16 seq. F. CAfagGI, 'On the Transformations of European Consumer Enforcement Law: Judicial and Administrative 
Member States enjoy procedural autonomy when providing for enforcement mechanisms and procedures aimed at rights protection in so far as the procedural rules that govern actions to safeguard an individual's rights under EU law are no less favourable than those governing similar domestic actions (principle of equivalence) and do not make it in practice impossible or excessively difficult to exercise rights conferred by EU law (principle of effectiveness). ${ }^{3}$ Moreover, Member States may define measures, sanctions and remedies to be provided on the occurrence of a violation of EU law so long as these are effective, proportionate and dissuasive. ${ }^{4}$

2. The concepts of effectiveness, proportionality and dissuasiveness have largely been shaped by judicial dialogue between the Court of Justice of the European Union (CJEU) and the national courts, only occasionally been expressly codified in EU legislation. ${ }^{5}$ In this article, these three principles will be examined mainly with reference to the area of remedies, here broadly understood as measures provided by enforcement mechanisms against the violation of legal rights. The institutional design of remedies should provide parties with right incentives to comply or to correct past inappropriate behaviour and judges with the power to select the appropriate combination, taking into account the concurrent operations of other forms of enforcement. These principles should be read in relation to Article 47 of the Charter of fundamental rights. ${ }^{6}$

3. As more broadly explained below having regard to current case-law and statutory law, effectiveness may be referred to as a principle enabling an adequate remedial response to a violation in terms of both (1) the remedy's aptness to in fact perform the function for which the remedy is designed (preventive, penal,

Trialogues, Instruments and Effects', in F. Cafaggi \& S. Law (eds), Judicial Cooperation in European Private Law (Cheltenham: Elgar 2017), p 223.

3 Among several judgments, see: ECJ 6 October 2009, Asturcom, C-40/08, para. 38; CJEU 18 February 2016, Finanmadrid EFC SA, C 49/14, para. 40. See T. Tridimas, The General Principles of EU Law, p 423.

4 See Art. 7 Dir. 93/13/EEC on Unfair Terms in Consumer Contracts; Arts 11 and 13 Dir. 2005/29/ EC on Unfair Commercial Practices; Art. 24 Dir. 2011/83/EU, Consumer Rights Directive.

5 See C. Timmermans, 'Looking Behind the Scene of Judicial Cooperation in Preliminary Procedures', in Judicial Cooperation, p 33; M. SAFJAN, 'Fields of Application of the Charter of Fundamental Rights and Costitutional Dialogues in the European Union', in Judicial Cooperation, p 51; A.J. ScIRICA, "The Structure of US Federal and State Courts and Mechanisms for Formal and Informal Resolution', in Judicial Cooperation, p 69. For an express quotation of the principles of effectiveness and equivalence, see e.g. Art. 4 Dir. 2014/104/EU on actions for damages for infringements of the competition law provisions. See in the field of unfair trade practices CJEU 16 April 2015, Nemzeti, C-388/13, para. 58, where the CJEU has given a clear indication of proportionality of sanctions in unfair commercial practices having regard to frequency of the practice complained of, whether or not it is intentional, and the degree of harm caused to the consumer. See M. SAFJan, in Judicial Cooperation, p 51. 
compensatory, restitutionary, etc.) ${ }^{7}$ and (2) the absence of obstacles (mainly procedural) that in fact prevent the attainment of these objectives, e.g. by causing a delayed remedial response, or requesting too high a burden of proof, etc. ${ }^{8}$ The factual and practical dimensions of effectiveness sit at the very core of this principle. It is important to underline that the effective protection of EU legal rights and the effectiveness of EU law do not necessarily coincide ${ }^{9}$; for example, the need for an effective enforcement of a law on asylum rights may lead to a lower level of protection for migrants in special circumstances. In fact, the principle of effectiveness does not necessarily ensure the highest level of protection but rather an adequate level, considering all circumstances and possible conflicts with other rights, whose relevance is at least as valuable as the one considered.

4. Pursuant to the legal approach established in EU law, the principle of proportionality will be framed within the tripartite test of adequacy, necessity, and proportionality stricto jure. To be proportional, a measure should be (1) apt for the purpose for which it is provided ${ }^{10} ;(2)$ its scope should be necessary in the sense that no other less intrusive means exist to attain an equivalent result; and (3) it should be strictly proportional with respect to both the size and the relevance of the infringement, on the one hand, and the size, quality, intensity of the effects generated by the remedy, on the other. ${ }^{11}$ As we see below, the principle usually calls for a balance between the interests of the infringing party and the ones of the victim or other general interests.

5. The principle of dissuasiveness mostly concerns the ability of the remedy to discourage future infringements. In many cases the mere fact that an effective and

7 See e.g. CJEU 13 July 2006, Vincenzo Manfredi, C-295/04, para. 95, on the effectiveness of damages.

8 See ECJ 16 December 1976, Rewe, C-33/76; ECJ 16 December 1976, Comet, C-45/76. See also Art. 4 Dir. 2014/104/EU. See more extensively, below s. 2.

9 See ECJ 26 February 2013, Melloni, C-399/11, para. 59. See M. SAFJan, A Union of Effective Judicial Protection. Addressing Multi-level Challenge Through the Lens of Article 47 CFREU (Oxford: Oxford University Press 2014), p 10.

10 See K. Gutman, The Constitutional Foundations of European Contract Law (Oxford: Oxford University Press 2014), p 306. Under this respect there is some overlapping between the principle of proportionality and the principle of effectiveness, whose scope is however stricter in terms of adequacy/aptness, provided that the test of effectiveness must be conducted in concreto rather than in abstracto.

11 See for a first acknowledgment, ECJ 17 December 1970, Internationale Handelsgesellschaft mbH, C-11/70. In more recent case law: CJEU 11 July 2002, Käserei, C-210/00, para. 59. See also the definition of proportionality in the Opinion of Advocate General Kokott, 14 October 2004, Berlusconi, Joined Cases C-387/02, C-391/02 and C-403/02. All these definitions relate to criminal and administrative measures; however, EU case law has acknowledged the relevance of the principle of proportionality as a general principle of EU law in the area of contract law as well (see Court of First Instance 25 May 2004, Distilleria Palma, T-154/01. 
proportionate measure is available should be sufficient to discourage future infringements. However, equally effective remedies may be more or less dissuasive, or disproportionate remedies may be very (if not too) dissuasive, depending on the relevant circumstances. In order to be dissuasive a remedy must, at least, (tend to) deprive the infringer of the benefits obtained (or due to be obtained) from the infringement, taking into account the costs/incentives for the victim(s) to enforce the remedy and the effects of the remedy on an individually harmful or multioffensive situation. ${ }^{12}$ Infringers' benefits are not merely monetary but may be linked with the opportunity to operate in a market, to set the standards within a supply chain or in a market, or to promote a brand. This explains why, as it is shown below, the principle of dissuasiveness applies to more remedies than simply monetary fines, including invalidity, injunctions and many forms of collective redress.

6. This article will examine the principles of effectiveness, proportionality and dissuasiveness as a triad. The concept of triad is used both as an illustration and as an analytical tool. It is an illustration since it reflects the frequent and contextual reference by EU secondary law to the three principles as distinct prescriptions to be complied with by the Member States. ${ }^{13}$ It is an analytical tool since it enables the interpreter to look at diversities and complementarities within the triad as part of a coherent and harmonious system of rules. Measures and remedies should provide parties with incentives to comply and, when infringements occur, to dissuade from engaging in a similar conduct in the future. This analysis becomes more challenging once the interpreter realizes that in fact the three principles may occasionally conflict with one another and that a balancing effort may be needed in order to attain the envisioned level of rights protection. ${ }^{14}$

The main purpose of this article is to examine the impact of the triad in the judicial dialogue that emerges among national and EU courts addressing consumer law cases. Consumer rights belong to the third generation (of political, civil, and economic rights). In the current legal landscape both at EU and national levels, legislators and policy makers have paid increasing attention to consumer rights. In some jurisdictions they have gained a constitutional status and/or have been

Opinion of Advocate General Kokott, C-387/02, para. 89. See in the area of non-discrimination, CJEU 17 December 2015, María Auxiliadora Arjona Camacho v. Securitas Seguridad España, SA, C-407/14.

13 See footnote n. 4, 10 above.

14 See e.g. CJEU 9 November 2016, Home Credit Slovakia a.s., C-42/15, para. 67 seq., where the Court acknowledges that a remedy for the failure to include mandatory information in a consumer credit contract may be effective and dissuasive but not proportionate depending on specific circumstances (see also, the Opinion of Advocate General Sharpston delivered on 9 June 2016 in the same case, para. 67 seq.). On this judgment see the comment by M.R. MAugeri, Omissione di informazioni e rimedi nel credito al consumo. La decisione della CGE 42/15 e la proporzionalità dell'apparato rimediale italiano, BBTC (Banca Borsa e Titoli di Credito) 2017, forthcoming. 
recognized as fundamental rights. ${ }^{15}$ Their effective enforcement has become a key issue in EU and national policies. ${ }^{16}$

7. More particularly, the analysis will focus on the configuration, the choice and the functioning of civil remedies in consumer law, analysing the case law arising in some of the Member States of the EU. By civil remedies we refer to measures that are primarily aimed at redressing the aggrieved consumer(s) by means for example, of an injunction, invalidity, restitution, repair, replacement, price reduction, damages or a combination of such remedies. The interaction between civil remedies and measures of public enforcement (including, e.g. administrative or criminal sanctions) will be examined at the end of the article through the lenses of the triad.

Based on the analysis of CJEU decisions and a selection of national cases, this article shows that the choice of effective, proportionate and dissuasive remedies is in the first place a task for the law-maker and then for the aggrieved party at the time of filing a claim before a civil court. However, in the majority of cases, national legislators fail to provide definitions of effectiveness, proportionality and dissuasiveness and implicitly 'delegate' the task to either the judiciary or administrative enforcers. The role of the enforcer and the strictness of the principles differ depending on whether the enforcement is criminal, administrative or civil. These differences require each enforcer to apply the principles in the context of multiple enforcement mechanisms, taking duly into account the effects of the other concurring enforcement mechanisms.

In the domain of private enforcement, the analysis below will show that, firstly, the judge plays (and shall play) an important function in setting the procedural conditions for an 'informed' remedial choice by the consumer; this function tends to prevail over a more paternalistic role whereby the judge chooses the remedies on behalf of the consumer. Secondly, freedom of contract may still contribute to the definition of effective, proportionate and dissuasive remedies through contractual clauses or separate agreements to the extent that such clauses/agreements protect the consumer and do not reduce his or her power to choose.

8. The analysis will be developed separately per each of the three principles (Sections 2 through 4 ) in order to address their distinct features within the triad. Section 5 will be devoted to the analysis of the complementarities among different modes of enforcement, including Alternative Dispute Resolution (ADR) sumer protection laws (Brussels, 25 May 2016, COM(2016) 283 final 2016/0148 (COD)). 
mechanisms, and the application of the triad across the board. Section 6 concludes and presents some of the many undeveloped questions that have emerged alongside the analysis as themes of future research.

\section{The Principle of Effectiveness}

9. Member States (MS) enjoy procedural autonomy provided that their legislation is no less favourable than that governing similar domestic actions (principle of equivalence) and does not make it in practice impossible or excessively difficult to exercise rights conferred by EU law (principle of effectiveness). ${ }^{17}$ The CJEU shows that the principle of effectiveness does not only aim at removing obstacles to effective protection but also provides guidelines for the (affirmative) identification of available procedures, remedies and sanctions. ${ }^{18}$

10. In the area of consumer law, the principle of effectiveness is aimed at ensuring a high level of consumer protection, as a specific objective for the EU policies established in Article 38, CFREU, and Article 169, TFEU. Pursuant to Article 19.1, TEU, it is a duty of the Member States to define effective remedies. EU secondary law states that Member States shall ensure that adequate and effective means exist to prevent and combat infringements in order to ensure compliance with EU consumer law and that penalties against the violation of its provisions shall be effective, proportionate and dissuasive. Occasionally, EU secondary law refers to the principle of effectiveness in the format of the 'Rewe judgment' wording. ${ }^{19}$

17 ECJ 6 October 2009, C-40/08, para. 38; CJEU 18 February 2016, C-49/14, para. 40. See T. Tridimas, The General Principles of EU Law, p 423; N. REIch, 'The Principle of Effectiveness and EU Contract Law', in J. Rutgers, \& P. Sirena (eds), Rules and principles in European Contract Law (Cambridge: Intersentia 2015), p 45 seq.; A. HaRTKamp, European Law and National Private Law (Cambridge: Intersentia 2016), p 100 seq.; A. Carratta, in Le 'libertà fondamentali', p 204 seq.

18 N. Reich, General Principles of EU Civil Law, p 97 seq.; A. HarTKamp, European Law, p 99. Indeed, with a more 'positive' view than the one focused on removing procedural obstacles, the Court has held that MS shall provide national remedies in order to 'guarantee real and effective judicial protection' of EU rights (see ECJ, 10 April 1984, Case C-14/83, von Colson, para. 23). The principle has also been extended to the right to judicial review and access to a competent court (see ECJ, 15 May 1986, Case C-222/84, Johnston, para. 17). See also EU Network of Independent Experts on Fundamental Rights, Commentary of the Charter of Fundamental Rights of the European Union, June 2006, http://ec.europa.eu/justice/fundamental-rights/files/networkcom mentaryfinal_en.pdf, sub Art. 47, 359. See Actiones Handbook on the Techniques of Judicial Interactions in the Application of the EU Charter - Consumer Protection, Florence, 2016, 70, on file with the authors.

19 See footnotes ns 10 seq. above and corresponding text. The role of general principles concerning the effective enforcement of consumer rights is also acknowledged at international level; see United Nations Guidelines for Consumer Protection, adopted in 1985, last modified in 2016, in particular paras $5(\mathrm{~g})$ and 37. 
11. Once transposed at the national level, the principle of effectiveness has to influence policy makers and enforcers in the identification of enforcement mechanisms (e.g. judicial v. administrative enforcement) and in the determination of measures against infringements, here understood as either remedies (primarily aimed at protecting the aggrieved party) or sanctions (primarily aimed at penalizing the infringer).

For example, the progressive expansion of administrative enforcement in consumer law can be interpreted as an attempt to improve the effectiveness of consumer protection through a higher reliance on ex officio investigation powers by administrative authorities, a reduced duration of enforcement proceedings, and a growing role of collective redress. ${ }^{20} \mathrm{~A}$ similar trend cannot occur at the expense of the guarantees of due process and fair trail principles, as established by Article 47, Charter of Fundamental Rights of the European Union(CFREU). Indeed, especially when administrative authorities are the only bodies vested with some enforcement powers, these guarantees must be specifically ensured in respect of administrative enforcement mechanisms. ${ }^{21}$ Here reference should be made to Article 47 CFREU, Article 41 CFREU and to the right of defense. ${ }^{22}$

In the case of wide or cross-border infringements, effectiveness may also require a high degree of coordination and cooperation among different competent authorities within a single MS and in several MSs according to the principle of loyal cooperation. $^{23}$

Moreover, the need to ensure an effective access to justice influences the use of ADR mechanisms when promoted or even imposed by law. ${ }^{24}$

12. Not only the choice between different enforcement mechanisms but also the application of different remedies and sanctions may be assessed through the lens of

20 See F. CAfaggi, 'The Great Transformation. Administrative and Judicial Enforcement In Consumer Protection: A Remedial Perspective', LCLRev (Loyola Consumer Law Review) 2009, p 496 seq.; O.O. Cherednychenko, ERPL 2015, p 485. See also H.W. Micklitz - G. Saumier, Enforcement and Effectiveness of Consumer Law, Draft General Report, 2016 Montevideo Thematic Congress, International Academy of Comparative Law, pp 4 seq.

21 See e.g. Art. 11(3) Dir. 2005/29/EC.

22 See Opinion of the Advocate General H. Saugmandsgaard Øe 2 June 2016, Biuro, C-119/15, para. 61.

23 See Regulation 2004/2006 and the current Proposal for a Regulation on cooperation between national authorities responsible for the enforcement of consumer protection laws (Brussels, 25 May 2016, $\operatorname{COM}(2016) 283$ final 2016/0148 (COD)), part. Arts 6 and 12. See F. Cafaggi, in Judicial cooperation, p 223.

24 See CJEU 18 March 2010, Alassini et al., Joined Cases C-317/08, C-318/08, C-319/08 and C-320/ 08, whose reasoning has been recently confirmed by Opinion of Advocate General Saugmandsgaard Øe delivered on 16 February 2017, Menini \& Rampanelli, C-75/16, paras 80 and 96 seq., concluding that, even though the law may provide for a mandatory mediation procedure, in order to ensure effective access to justice, the consumer shall be free to exit the procedure at will without bearing adverse consequences. 
the principle of effectiveness. For example, if the main purpose is compensation, the principle of effectiveness may be linked with the rule on full compensation. ${ }^{25}$ When restitution is at stake, effectiveness ensures that the consumer is given back what she would have had if the infringement had not been committed. ${ }^{26}$ If the main objective is sanctioning the infringer, an effective penalty must be determined so as to materially deprive that party of relevant resources or opportunities.

Effectiveness may influence the choice between alternative remedies within the same enforcement system (e.g. repair v. contract termination); moreover, it may contribute to the creation of a hierarchy of remedies (where the most effective remedy ranks first) or suggest complementarities, e.g. between injunctive and penalty measures. ${ }^{27}$ Additional elements must be considered when remedies differ in relation to different enforcement systems. ${ }^{28}$

13. In the domain of private enforcement, the CJEU has repeatedly linked the assessment of effective consumer protection with the need for rebalancing the uneven relationship between consumers and professionals and the ultimate goal of enabling a smooth functioning of the European internal market. ${ }^{29}$

The need to rebalance the 'consumer-business' relation is no longer a pivotal reference to assess effectiveness when collective enforcement mechanisms are at stake, e.g. when consumer associations bring an action for an injunction in the public interest. ${ }^{30}$ In this case, effectiveness should be linked with the dissuasive and deterrent effect of injunctions and with the collective dimension of its effects. ${ }^{31}$ Hence, the principle of effectiveness operates differently depending on whether redress is individual or collective and on the status and identity of the claimant.

14. This section is structured as follows. It addresses the impact of the principle of effectiveness on the use of some civil enforcement remedies, such as the

See Art. 3 Dir. 2014/104/EU on antitrust damages. See also with regard to the Manfredi case (CJEU, case C-295/04), R. Stefanicki, 'Civil Law Remedies for Violation of Competition Law', 8 ERCL (European Review of Contract Law) 2012(4), p 400 seq.

26 See CJEU 21 December 2016, Gutiérrez Naranjo et al., Joined Cases C-154/15, C-307/15 and C-308/15, para. 73. See, in the Spanish law perspective, J.M. Fernàndez Seijo, La tutela de los consumidores en los procedimientos judiciales (Barcelona: Kluwer 2017), p 126 seq.

27 See e.g. Art. 2(1)(c) Dir. 2009/22/EC on the use of injunctions for consumer protection.

28 See s. 5 below.

29 See, among several ones, ECJ 6 October 2009, Asturcom, C-40/08, para. 29. See also, addressing this balancing in the light of efficiency and justice, E. NAVARrETTA, "Il contratto "democratico" e la giustizia contrattuale', RDC (Rivista di diritto civile.) 2016(5), p 1262 seq.

30 Indeed consumer associations already play a role in rebalancing the consumer-professional relationship. See CJEU 14 April 2016, Sales Sinués, Joint Cases C-381/14 and C-385/14, para. 27. See V. Zeno-Zencovic \& M.C. Paglietti, Diritto processuale dei consumatori (Milano: Egea 2009), p 41 seq.; J.M. Fernàndez SeIJo, La tutela de los consumidores, p 137 seq.

31 See CJEU 14 April 2016, C-381/14, para. 29; Opinion of the Advocate General, C-119/15, para. 74. 
invalidity of unfair terms (2.1), the invalidity of contracts affected by unfair commercial practices or the violation of information duties (2.2), and damages (2.3).

\subsection{Effectiveness and the Expanding Scope of Non-bindingness of Unfair Terms}

15. The principle of effectiveness has significantly shaped the scope and rules of consumer protection in the domain of the non-bindingness of unfair contract terms. In this section we examine whether the principle has contributed to the consolidation of new remedies (mainly civil injunctions) and to redefine the scope and nature of existing remedies (mainly invalidity). Indeed, we submit that it has done so. We leave out of this analysis the relationship between effectiveness and ex officio powers widely assessed by the CJEU and explored in EU legal scholarship. $^{32}$

16. Pursuant to Article 6.1 Directive 93/13, Member States shall lay down that unfair terms used in a contract concluded with a consumer by a seller or supplier shall, as provided for under their national law, not be binding on the consumer and that the contract shall continue to bind the parties as to its other terms. The CJEU has also held that this is a mandatory provision which aims to replace a formal with an effective balance that re-establishes equality between the parties. ${ }^{33}$ This is a case in which the outcome pursued by the effective remedy is already defined by EU secondary law through a 'neutral' concept (non-bindingness) ${ }^{34}$; it is for the Member States to choose between nullity, voidability, or unenforceability to achieve effectiveness. The choices of the Member States have largely differed, without reducing the effectiveness of consumer protection. ${ }^{35}$

See ECJ 27 June 2000, Océano Grupo Editorial SA, Joined Cases C-240/98 to C-244/98; ECJ 26 October 2006, Elisa María Mostaza Claro v. Centro Móvil Milenium SL, C-168/05; ECJ 4 June 2009, Pannon GSM Zrt. v. Erzsébet Sustikné Győrfi, C-243/08; ECJ 6 October 2009, Asturcom, C-40/08; CJEU 14 June 2012, Banco Español de Crédito SA v. Joaquín Calderón Camino, C-618/ 10; CJEU 14 March 2013, Mohamed Aziz v. Caixa d'Estalvis de Catalunya, Tarragona i Manresa (Catalunyacaixa), C-415/11; CJEU 26 January 2017, Banco Primus SA, C-421/14.

33 CJEU 30 May 2013, Asbeek Brusse, de Man Garabito v. Jahani BV, C-488/11, para. 38, citing, inter alia, Banco Español de Crédito (Case C-618/10), para. 40, and Banif Plus Bank (C-472/11), para. 20 .

34 See Opinion of Advocate General Trstenjak 6 December 2011, Invitel, C-472/10, para. 48. See also F. CAFAGGI \& S. LAW, 'Unfair Contract Terms - Effect of Collective Proceedings', in E. Terryn, G. Straetmans \& V. Colaert (eds), Landmark Cases of EU Consumer Law. In Honour of Jules Stuyck (Cambridge: Intersentia 2013), pp 653-676.

35 See Report from the Commission on the implementation of Council Directive 93/13/EEC of 5 April 1993 on Unfair Terms in Consumer Contracts, COM(2000) 248 final, Brussels, 27 April 2000, p 19. See for a comparative view R. Steennot, 'Public and Private Enforcement in the Field of Unfair Contract Terms', ERPL (European Review of Private Law) 2015(4), p (589) at 599. 
A second aspect of effectiveness is explicitly addressed by Article 7 Directive $93 / 13 / \mathrm{EC}$, in respect of the situation wherein the same or similar terms are used by the same or other professionals. Here the unfairness is ascertained in abstracto without regard to the use of the term in a specific contract. ${ }^{36}$ In these cases, the principle of effectiveness calls for measures that can expand the reach of remedies to benefit all possible consumers suffering from a given form of unfairness (considered, in its substantive and practical elements, to be beyond any formalistic definition). Firstly, the non-bindingness should extend to terms used by the same professional with consumers who are not parties in the proceedings. ${ }^{37}$ Secondly, it should extend to terms used by the same professional, which are similar and functionally equivalent to those declared unfair, although presented with a different wording. ${ }^{38}$ Thirdly, effective consumer protection could lead to an extension to identical or even similar terms used by other professionals in the same sector. ${ }^{39}$ Fourthly, such an extension may not merely relate to terms already used before the decision declaring the existence of unfairness but should also extend to future uses. $^{40}$

This multiple extension is clearly envisioned as having the aim of increasing the effectiveness of consumer protection. ${ }^{41}$ The way in which, along the lines of Article 7(3), Unfair Terms Directive, the 'remedies' should be 'directed' against one or more professionals depends on national enforcement systems with special regard to rules concerning standing to sue and the scope of res judicata. ${ }^{42} \mathrm{~A}$ balance may be sought in this respect between effectiveness and the right to a

37 See CJEU 26 April 2012, Invitel, C-472/10, para. 42 seq.; F. CAFAGGI \& S. LAW, in Landmark Cases, p 653; A. Carratta, in Le 'libertà fondamentali', p 222.

38 See Art. 7(3) Dir. 93/13/EEC, when referring to 'similar' terms. See also Report on the implementation of Council Directive 93/13/EEC, COM(2000) 248 final, 23.

39 This is the case in which the action is brought by a consumer association against multiple undertakings or a professional association under Art. 7(3) Dir. 93/13/EEC. See also Report on the implementation of Council Directive 93/13/EEC, 22.

40 See CJEU 26 April 2012, C-472/10, para. 43.

41 Opinion of Advocate General Trstenjak 6 December 2011, C-472/10, para. 36 seq.; Opinion of the Advocate General, C-119/15, para. 40; CJEU 21 December 2016, C-119/15, para. 34.

42 See ECJ 6 October 2009. C-40/08; CJEU 26 January 2017, C-421/14. With regard to national legislation, see, for example, the reform brought in 2014 in the French Consumer Code providing for the possibility of actions brought by consumer association for the declaration of term unfairness in all identical contracts signed by the same professional involved in that case, as well as model contracts or those that are no longer offered (Art. L 421-6). See G. Busseuil, 'Implementation of Consumer Rights Directive: France', JoECM (Journal of European Consumer and Market Law) 2014, p 273, observing that this rule is aimed at making enforcement of consumer rights more effective. See also the Spanish legislation on the formation of a register of contractual terms declared unfair by final court decisions, providing for an erga omnes effect to the extent that anybody can invoke the unfairness of these terms before other Spanish courts and instances (see Transposition Act n. 7/1998 of 13 April 1998). 
fair trial for the benefit of affected professionals from the perspective of Article 47, CFREU. $^{43}$

17. One could observe that such 'reinforced' effect of non-bindingness aims at playing a two-fold role; that is, as a declaratory remedy and as an injunction directed at preventing its future use. The application of the principle of effectiveness has favoured the extension of injunctive powers within private enforcement context and the rise of declaratory powers within public enforcement: as such, administrative authorities, which may use injunctions, are allowed to 'declare' the term unfair and therefore enable any consumer to benefit from this judgment. To what extent and how such ascertainment, as made by either a court or an administrative authority, may be referred to by any interested consumer depends on procedural rules established at MSs' level. ${ }^{44}$

Since the Invitel case these 'expanding' effects of declaratory decisions are considered by the CJEU to be correlated to the principle of effectiveness and therefore necessary for effective consumer protection, ${ }^{45}$ provided that they do not violate the enterprise's right of defence and that the need for collective redress does not hinder the individual consumer's right to oppose the declaration of the term's unfairness. ${ }^{46}$ Indeed, as far as the erga omnes effects operate in favour of persons not participating into the proceedings, they grant effective protection without impairing any fair trial principle. ${ }^{47}$

18. Effective protection should also be balanced with the principle of legal certainty as a general principle of EU law. ${ }^{48}$ Moving from this perspective, in some Member States, professionals may seek an ex ante assessment of terms'

43 See Opinion of Advocate General Trstenjak 6 December 2011, C-472/10, para. 57 seq., and, explicitly referring to Art. 47 CFREU: Polish Supreme Court, 20 November 2015 (Supreme Court III CZP 17/15); Opinion of the Advocate General, C-119/15, para. 58 seq.; CJEU 21 December 2016, C-119/15, para. 40.

44 This extension could be attained, e.g. by considering the evidence of former proceedings on the same matter and terms as automatically relevant or binding for future proceedings or by vesting future consumer plaintiffs with a right to get an invalidity decision by simply referring to the previous proceedings. See, for France, footnote n. 42, 46 above. For legislation in Hungary (part. Art. 209B(1), civ. code) see the analysis drawn in the judgment on the Invitel case. For other references to national law, part. Spain and the Netherlands, see also F. CAAfagGI \& S. LAW, in Landmark Cases, p 653. For Belgium see R. SteEnNot, ERPL 2015, p 616.

45 H.W. Micklitz, 'A Common Approach to the Enforcement of Unfair Commercial Practices and Unfair Contract Terms', in W. van Boom, A. Garde \& O. Akseli (eds), The European Unfair Commercial Practices Directive (London and New York: Routledge 2014), p 189 seq.

46 Opinion of the Advocate General, C-119/15, paras 58 seq., and 74; CJEU (Fifht Chamber), 21 December 2016, in the same case, para. 40 seq. On the latter point see, more extensively, CJEU 14 April 2016, Sales Sinués, Joint Cases C-381/14 and C-385/14.

47 See Opinion of Advocate General Trstenjak 6 December 2011, C-472/10, para. 59 seq.

48 See CJEU 21 December 2016, C-119/15, paras 35 and 39; Opinion of the Advocate General, C-119/15, para. 57. 
(un)fairness by the competent administrative authority, which may also be in charge of the ex post control. For example, in France the Commission pour clauses abusives renders ex ante opinions that are not binding for the courts. ${ }^{49}$ In case that the term is considered unfair, the administrative authority (but not the court) is bound by this opinion when exercising decision power ex post. In practice, private and public enforcement systems are not reciprocally neutral; indeed, while the decisions of an administrative authority are not binding for a court, they may in fact become very influential. Hence, even if a court is not bound by an ex ante opinion rendered by an administrative authority, it is rather rare that it would contradict such decision.

19. The growth of reliance on injunctive measures via a combination of private and public enforcement mechanisms is favouring a mixture of cooperative and punitive remedial design, which can be easily framed within the principle of effectiveness. On the one hand, especially within public enforcement proceedings, a collaborative approach to enforcement is emerging, which is partially shown in the above-mentioned practice of ex ante control. ${ }^{50}$ A similar example relates to legislation allowing for the public authority's acceptance of formal commitments taken by the professional aimed at ceasing and desisting from the infringement and correcting its consequences. ${ }^{51}$ On the other hand, national enforcement systems tend to reinforce the effectiveness and dissuasiveness of injunctions through the use of astreintes as an ex post response to persisting infringements. ${ }^{52}$ Along these lines, some national judges tend to extend the use of astreintes beyond the enforcement of injunctive redress and to apply them in case of lack of compliance with monetary penalties. ${ }^{53}$ The principle of effectiveness has contributed to the expansion of the effects of injunctions beyond the scope of litigation in order to strengthen the market policing power both in relation to unfair terms and unfair

49 See Commission des clauses abusives, established by Art. L. 534-1 French Cons. Code, or the role of the Italian Competition Authority under a similar respect (Art. 37-bis(3) Italian Consumer Code).

50 See F. Cafaggi \& H.W. Micklitz (eds), New Frontiers of Consumer Protection - The Interplay Between Private and Public Enforcement (Mortsel: Intersentia 2009), pp 401-446.

51 See e.g. Art. 27(7) Italian Consumer Code on the role of the Competition Authority in case of unfair commercial practices and its power to obtain from the professional serious commitments of cessation or modification of the addressed practice; Art. 75 Hungarian Competition Act, as applicable to unfair commercial practices. See V. Balogh \& K.J. Cseres, 'Institutional Design in Hungary: A Case Study of the Unfair Commercial Practices Directive', 36. JCP (Journal Consumer Policy) 2013, p (343) at 358; F. Cafaggi \& H.W. Micklitz (eds), New Frontiers, p 401.

52 See Art. 2(1)(c) Injunction Directive, and in MSs legislation, e.g. Art. L 421-2 French Consumer Code, on collective civil actions by consumer organizations, Art. 140(7) Italian Consumer Code. See for more references, Report from the Commission, Concerning the application of Directive 2009/22/EC on injunctions for the protection of consumers' interest, Brussels, 6 November 2012, $\operatorname{COM}(2012) 635$ final, 13.

53 See, in the Italian case law, Consiglio di Stato (Joint Chambers) 25 June 2014, no. 15. 
practices. We shall examine below whether the combination of the principle of effectiveness and proportionality calls for an explicit coordination and escalation between ex ante (cooperative) enforcement and (ex post) penalty remedies.

\subsection{Effectiveness of Civil Remedies in the Enforcement of Consumer Rights Against Unfair Commercial Practices, Lack of Transparency and Failure to Inform}

20. The definition of effective remedies in the area of unfair commercial practices has followed a different path. ${ }^{54}$ Despite the specific reference to effectiveness, proportionality and dissuasiveness in the 2005/29 Directive, the use of the triad has been limited in CJEU jurisprudence. ${ }^{55}$ In this area the focus is definitely (and has always been) on 'collective harm' more than on the need to protect individual rights. ${ }^{56}$ Effectiveness of collective redress may be evaluated slightly differently from individual injury since the class of harmed consumers may have different and at times even divergent interests as to the type of remedy and the objective of protection: some may be more interested in stopping the practices, others in restitution, others in damages.

21. The involvement of administrative authorities in policing unfair commercial practices is central in almost all MSs. ${ }^{57}$ Access to courts is specifically provided for consumer groups, consumer organizations and public bodies with the aim of

54 Unlike unfair contract term the role of effectiveness in UCPD case law has been much less relevant both in relation to ex officio and in relation to remedies. In theory there is no reason for such a disparity and the principle of effectiveness and the right to an effective remedy should play as a relevant role as that performed in the evolution of unfair contract terms.

55 Dir. 2005/29, Art. 13, concerning penalties explicitly state: 'Penalties must be effective, proportionate and dissuasive.'

56 The term 'mass harm situation' is derived from the Recommendation on collective redress (footnote 53, 56 above). However, this reference does not imply that unfair practices herein examined shall be materially harmful for several consumers; see CJEU 16 April 2015, UPC Magyarország $K f t$, C-388/13, (see for a comment M. Durovic, "The Meaning of the Notion "Commercial Practice" Under EU Law: UPC Magyarország”, 12. ERCL (European Review of Contract Law) 2016(1), pp 57-71). Regardless its individually or collectively harmful nature, an unfair practice is conceived as an extra-contractual act in respect of private international law. See CJEU 28 July 2016, Amazon EU Sarl, C-191/15.

57 See Commission, First Report on the application of Directive 2005/29/EC ('Unfair Commercial Practices Directive'), Brussels, 14 March 2013 COM(2013) 139 final, 26. See also: V. BALOGH \& K. J. Cseres, 36. JCP 2013, p 351; D. PoelzIG, 'Private or Public Enforcement of the UCP Directive? Sanctions and Remedies to Prevent Unfair Commercial Practices', in W. van Boom, A. Garde \& O. Akseli (eds), The European Unfair Commercial Practices Directive (London and New York: Routledge 2014), p 256 seq; see also the Country Reports on the implementation of the Consumer Rights Directive, published in JECML (Journal of European Consumer and Market Law) 2014, and coordinated by G. De Cristofaro \& A. De Franceschi. 
seeking mostly injunctions, sometimes replaceable with infringer's commitments to cooperate and desist. Administrative fines are also commonly provided as specific remedies for infringements in these areas. ${ }^{58}$ The use of civil penalties by judges and administrative penalties by authorities strengthens the enforcer's ability to police market practices and to signal and discourage other potential violations. Clearly, their combination may raise questions related to proportionality and dissuasiveness. ${ }^{59}$

Implementation has followed different trajectories on the relative weight of administrative and criminal sanctions for violations of consumer law, leaving private enforcement primarily, though not exclusively, to the existing set of remedies in the area of general contract law and/or torts. ${ }^{60}$ Only in some cases national legislation has provided specific remedies concerning the contract affected by an unfair practice or the violation of an information duty. ${ }^{61}$ To be precise, this type of remedy has been used relatively often in the implementation of the consumer credit directive $^{62}$ while more seldom in the implementation of the unfair practices ${ }^{63}$ and

58 See European Commission - DG Justice, Study on the application of Directive 2005/29/EC on Unfair Commercial Practices in the EU, Part 1 - Synthesis Report, part. 25.

59 See below, ss 3.3 and 4 .

60 For an implied reference to general contract rules on validity see also Art. 3(2) Directive 29/2005/ EC; Art.10 (1) Consumer Credit Directive. See the ground for contractual liability already in Art. 6 (5) Consumer Right Directive, in respect of failure to inform in distance contracts and off-premises ones. See also recital 25 Consumer Credit Directive. On the relation between Dir. 29/2005/EC and general contract law and its possible impact on the vices of consent as regulated at national level, see M. Durovic, 'The Subtle Europeanization of Contract Law: The Case of Directive 2005/29/EC on Unfair Commercial Practices', ERPL (European Review of Private Law) 2015(5), p (715) at 742 seq. See also H. W. Mickuitz, in The European Unfair Commercial Practices Directive, p 177 seq.

61 Going beyond the EU legislation expressly stating that directive 2005/29 applies without prejudice of national contract laws. The interplay between the two fields is clear and when legislation has not been adopted national judges have had to solve the correlation on a case by case basis. See M. Durovic, ERPL 2015(5), p 744

62 Indeed, in this area the majority of Member States rely on civil law remedies against lack of transparency on contract conditions (particularly on credit costs); different options emerge across countries from nullity, to withdrawal, contract termination, terms' reduction, exclusion of interest, etc. See T. Nwaogu et al., Study on the Impact of the Legal Choices of the Member States and Other Aspects of Implementing the Directive 2008/48/EC on the Functioning of the Consumer Credit Market in the European Union, prepared for the Executive Agency for EU Health and Consumers, October 2013, p 117 seq. For an application in the CJEU's jurisprudence, see CJEU 21 April 2016, Radlinger, C-377/14, emphasizing, in the light of the principle of effectiveness, the role for judicial ex officio powers to ascertain violation and derive the consequences provided by national law (nullity). In some instances, national courts have chosen invalidity on the basis of the principle of effectiveness (Dutch Supreme Court, 12 February 2016, Lindorff/X, ECLI: NL:HR:2016:236).

63 More particularly, in some MSs like France, the Netherlands, Luxembourgh and the UK, the consumer has been enabled to set aside the contract concluded on the basis of unfair commercial practices through different means (voidability, unwinding). See M. Durovic, ERPL 2015(5), p 744; 
the consumer rights directives. ${ }^{64}$ Lacking a specific remedy, the ordinary rules on vices of consent may fail to effectively protect consumer whenever, as is mostly the case, these rules require a specific link between the factual circumstances causing the vice of consent and the formation of the contractual consent as materially affected by those circumstances and unfair practices. ${ }^{65}$

22. An interesting remedial response is available under the Belgian law, that, without resorting to invalidity or express termination, enables the consumer to claim reimbursement or refuse payment without a duty to return the goods or compensate the service provided. ${ }^{66}$ We shall elaborate below on whether the principles of proportionality and dissuasiveness may help understand the scope and application of this special remedy. In the perspective of effectiveness two points should be emphasized: on the one hand, the measure tends to turn a consumer fraud into a consumer bargain (the consumer may keep the goods or services for free) and therefore to award the consumer with an economically advantageous remedy; on the other hand, the law seems to impose quite a high burden of proof on the consumer, hence making difficult in practice to exercise the assigned right. ${ }^{67}$ Moreover, one could wonder whether restitution will ever be (effectively) claimed and obtained by consumers and how often, especially in online markets, professionals will have been careful in securing advance payment, so in fact neutralizing the risk of payment refusal. ${ }^{68}$

V. MAK, 'Unfair Commercial Practices and Dutch Private Law', JECML (Journal of European Consumer and Market Law) 2016(6), p 246 seq; J. Devenney, 'Private Redress Mechanisms in England and Wales for Unfair Commercial Practices', JECML (Journal of European Consumer and Market Law) 2016(2), p 100 seq. See also P. Iamiceli, Unfair Practices in Business-to-Consumer and Business-to-Business Contracts: A Private Enforcement Perspective', RBEP (Revista Brasileira de Etudos Politicos) 2017, forthcoming.

64 See Country Reports on the implementation of the Consumer Rights Directive, JECML 2014.

65 See e.g. Italian Supreme Court (Corte di cassazione) 20 September 2013, no. 21600. For a different view, see F. CAfagGr, 'From a Status to a transaction-based approach? Institutional design in European Contract Law', CMLR (Common Market Law Review) 2013, p 311 seq. For a comparative analysis see F.P. PAтTI, 'Fraud and Misleading Commercial Practices: Modernising the Law of Defects in Consent', Published Online: 13 December 2016, DOI: https://doi.org/10. 1515/ercl-2016-0017, and for an optimistic view on the effectiveness of private enforcement mechanisms in financial market litigation, see F. Della Negra, 'The Private Enforcement of the MiFID Conduct of Business Rules. An Overview of the Italian and Spanish Experiences', 10. European Review of Contract Law (ERCL) 2014(4), pp 571-595.

66 See Art. VI.38 Belgian Code of Economic Law. R. Steennot, ERPL 2015, p 188 seq.; M. Durovic, ERPL 2015(5), p 743.

67 R. STEENNOT, ERPL 2015, p 190.

68 From this perspective the remedy is comparable with the one adopted by the Consumer Practice (Amended) Regulations1999 (CPAR 2014) in England and Wales, where Regulations 27L(1) vests the consumer, who has not resorted to unwinding (see above), with a partial restitutionary right (namely a discount) in both cases in which the consumer has already made payment(s) or no payment has been made. The regulation is applicable to contracts concerning product whose value 
23. The analysis shows that the principle of effectiveness may have effects beyond the strict domain of EU law as in the case of invalidity and restitution related to contracts based on an unfair commercial practice. ${ }^{69}$ It also demonstrates that, unlike unfair contract terms, the effectiveness of remedies in Unfair Commercial Practices Directive (UCPD) has not yet been adequately analysed by the Court of Justice. A closer scrutiny would reveal the shortcomings of separating unfair commercial practices from contracts and the consequences on the validity when mass deception has taken place. Likewise, along a similar path to that followed in antitrust cases, consumers' damages could be awarded as effective remedies. ${ }^{70} \mathrm{~A}$ good illustration is certainly represented by the dieselgate litigation concerning VW and other car manufacturers.

Furthermore, there is no reason to believe that the expansion produced by Invitel and Biuro of the effects concerning injunctive relief cannot also apply to unfair commercial practices. Both on the consumer side with Invitel and on the professional side with Biuro, the findings of an unfair term apply to other consumers and other professionals. Likewise, we contend, similar outcomes may result in the field of unfair commercial practices. Accordingly, if a commercial practice is deemed aggressive or misleading, this finding should apply to other consumers which are not technically parties to the judicial proceedings and should enable them to claim invalidity and/or damages when applicable law provide these as an effective remedy against unfair practices.

\subsection{Effectiveness of Damages? Lessons Learnt from Consumer Protection Against Competition Law Infringements}

24. Although damages are only occasionally mentioned in EU consumer legislation, they play an important role for effective consumer protection. We examine separately the compensatory and the deterrent or dissuasive effects of monetary measures that include punitive damages and astreintes. ${ }^{71}$ Effectiveness requires full or integral compensation. ${ }^{72}$ The effectiveness of this remedy is hindered by the consumer's limited incentives to sue the infringer due to the normally low value of individual harm. ${ }^{73}$ Another barrier may be represented by the burden of proof,

exceeds GBP 5000. On the application of the proportionality principle to this remedy see below para. III.3.3.

On the relationship between unfair commercial practices and unfair terms as ground for invalidity of the terms or the whole contract, see: CJEU 15 March 2012, Jana Pereničová, C-453/10; Opinion of Advocate General Kokott, 15 September 2016, Ramón Margarit Panicello, C-503/15. See s. 2.3 here below.

71 See below s. 4.

72 See CJEU 17 December 2015, C-407/14, para. 37.

73 Both the EU initiatives on Small Claims Procedure (see Regulation (EC) No 861/2007 of 11 July 2007) and on collective compensatory redress (Commission Recommendation of 11 June 2013 on 
often a burdensome task for the consumer to substantiate the evidence of the suffered harm and the one of the causal link between the infringement and the harm. ${ }^{74}$ Clearly this problem may be mitigated when multiple enforcement mechanisms are in place and the administrative enforcer proceeds ex officio to detect the violation. ${ }^{75}$

This is where the principle of effectiveness may play an important role, by removing the obstacles opposing to the effective exercise of consumer rights to claim damages derived from professionals' violation of their rights. It is not by chance that the recent directive on damages for infringements of competition law (Dir. 2014/104) explicitly incorporates in a black letter provision the principle of effectiveness (and that of equivalence) as developed by the CJEU ${ }^{76}$ and again recalls it when regulating the quantification of damages. ${ }^{77}$ The possibility to consider as irrefutably established a final decision released by a competition authority or a review court (Art. 9) as well as the relative presumption of the existence of a harm coming from the occurrence of an unlawful cartel (Art. 17.2), are rules certainly linked with the principle of effectiveness. A similar approach is shown by the Regulation $261 / 2004$ on flight passengers' protection when rules providing standard compensation are not requiring any specific evidence of damages. ${ }^{78}$

25. The role for damages goes beyond these expressly regulated cases at EU level. Indeed, they still remain among the general civil remedies provided by MSs against any act that can be considered as a breach of contract or a tort. Many national

common principles for injunctive and compensatory collective redress mechanisms in the Member States concerning violations of rights granted under Union Law (2013/396/EU)) may be considered as a response to the shortcomings of compensatory remedies in the EU context. On the victims' incentives to sue, see F. Weber \& M. Faure, 'The Interplay Between Public and Private Enforcement in European Private Law: Law and Economics Perspective', 23 ERPL (European Review of Contract Law) 2015, p (525) at 533.

74 The principle of effectiveness has easened the burden of proof and empower judges to make access to justice and to an effective remedy easier for consumers. See CJEU 4 June 2015, Froukje Faber v. Autobedrijf Hazet Ochten BV, C-497/13.

75 See below s. 5 .

76 See Art. 4 Dir. 2014/104/EU of 26 November 2014 on certain rules governing actions for damages under national law for infringements of the competition law provisions of the Member States and of the European Union.

77 See Art. 17 Dir. 2014/104/EU, where the link between effectiveness and the amount of damages is clearly defined. The directive points out that if, the claimant is unable to bear the burden of proof, national judges should be empowered to estimate the effective amount.

78 See Reg. n. 261/2004, Art. 7 on the right to compensation and Art. 12 on the right to further compensation. This regulation has been addressed by the European Court of Justice in the light of the principle of effectiveness calling for an extension of the remedy in the area of flight delay. See ECJ, 19 November 2009, Joint Cases C-402/07 and C- 432/07, Sturgeon and Boeck and the comment in N. Reich, General Principles of EU Civil Law, p 95. See also CJEU 15 January 2015, Ryanair Ltd v. PR Aviation BV, C-30/14. 
systems consider damages as a remedy applicable against the violation of rules implementing the Unfair Commercial Practice directive, ${ }^{79}$ the Consumer Credit directive, ${ }^{80}$ the Consumer Rights directive. ${ }^{81}$ In many cases general contracts or torts law apply, including those developed within unfair competition law as a branch of torts. Among those systems that have introduced special provisions on damages for the case of unfair commercial practices, it is worth noting the use of presumptions, as derived from a recital of directive 2005/29/EC on unfair commercial practices. ${ }^{82}$ Such presumptions are often related to the existence of the infringement and may identify a specific defence for the trader. ${ }^{83}$ Indeed, the access to this remedy may be problematic when proof of the amount of damages and causal link is required. ${ }^{84}$ Even beyond current applications, the principle of effectiveness should help courts to use presumptions in order to award compensatory remedies whenever unfair practices have caused losses that may not be addressed through the mere use of public enforcement mechanisms and the one of contract invalidity, if ever available.

26. Effectiveness applies to national legal systems when devising the remedies. It is compatible with procedural autonomy but it constraints MS choices. The brief comparative analysis shows that different combination between administrative and judicial enforcement have been chosen and within the latter that the array of remedies does not sufficiently innovate to promote effective consumer remedies. In such a legislative framework, the role of national judges is likely to increase crafting new remedies that reflect the policy objectives of the directives and the fundamental right to effective judicial protection in Article 47 CFR. Within this scenario, the principle of effectiveness may play an important role, even beyond its current application: (1) by empowering courts to ex officio ascertain infringements and apply these remedies, when available under national $\mathrm{law}^{85} ;(2)$ by creating

79 See D. Poelzig, in The European Unfair Commercial Practices Directive, p 250 seq., doubting about the effectiveness of compensatory individual redress provided in several MSs (e.g. Greece, Poland, Portugal, Ireland), due to consumers' reluctance to claim damages for small losses.

80 Damages are however by far less used for violations of consumer credit legislation in comparison with the other directives cited in the text. See T. Nwaogu et al., Study on the Impact of the Legal Choices of the Member States, p 120.

81 See Country Reports on the implementation of the Consumer Rights Directive, JECML 2014 . See s.2.2 above.

82 See Dir. 2005/29/EC, recital (21).

83 See e.g. UK Consumer Protection (Amendment) Regulations 2014, s. 27J(5); Art. 6:193j sub 1 Dutch Civil Code.

84 See V. MAK, JECML 2016, p 247.

85 On ex officio power to declare nullity for breach of information duties under the consumer credit legislation in Czech Republic, see CJEU, C-377/14. See F. BARTOLINI, 'The Consumer-Debtor Dimension: Some Further Steps for the Principle of Effectiveness within Consumer Credit Contracts', 12. ERCL (European Review of Contract Law) 2016(3), pp 292-305; S. PaGliantini, 
paths for renewed interpretation of general contract law towards effective consumer protection within the frameworks of national legal traditions; (3) by devising procedural rules that reallocate the burden of proof and alleviate the entry costs in judicial and administrative systems; (4) by expanding the effects of injunctions related to unfair contract terms and unfair commercial practices.

Remedial innovation is on the wave and EU principles still have a long way to go.

\section{The Principle of Proportionality}

\subsection{The Principle of Proportionality in the Enforcement of EU Rights: Definition and Scope of Application}

27. Proportionality is a general EU principle with different features in the MS. ${ }^{86}$ Proportionality can determine the content, the combination of remedies, and the relationship among enforcement procedures. It can have an impact on the sequence among different enforcement mechanisms and on their coordination. ${ }^{87}$ Regarding the use of sanctions and remedies, proportionality can affect (1) the content of the remedy, (2) the combination of remedies, (3) the sequencing of remedies, and (4) the definition of a hierarchy.

The CJEU has repeatedly defined proportionality as a general principle of EU law. ${ }^{88}$ The principle of proportionality has been used as a limitation to the legislative competence of the EU, as a ground for review of EU measures, as a ground for review of national measures affecting fundamental freedoms. ${ }^{89}$ In this last function, the principle is referred to by Article 52(1), CFREU,

'L'interpretazione dei contratti asimmetrici nel canone di Gentili e della Corte di Giustizia', Contr. (I Contratti) 2016(11), p 1029 seq.

86 See T. Tridimas, The General Principles of EU Law, p 137; N. ReIch, 'How Proportionate is the Proportionality Principle? Some Critical Remarks on the Use and Methodology of the Proportionality Principle in the Internal Market Case Law of the ECJ', in H.-W. Micklitz \& B. De Witte (eds), The European Court of Justice and the Autonomy of the Member States (Cambridge and Antwerp: Intersentia 2012), p 81 ss.

87 E.g. with regard to the coordination between voluntary settlement and judicial proceedings; see below s. 2.2 with regard to CJEU 18 March 2010, C-317/08.

88 See e.g. ECJ 17 December 1970, Internationale Handelsgesellschaft mbH v. Einfuhr- und Vorratsstelle für Getreide und Futtermittel; ECJ 16 December 1992, Commission / Greece, C-210/ 91; ECJ 11 July 2002, Käserei Champignon Hofmeister GmbH \& Co. KG and Hauptzollamt Hamburg-Jonas, C-210/00, para. 59. See also: T. Tridimas, The General Principles of EU Law, $\mathrm{p}$ 136 seq.; N. ReICH, General Principles of EU Civil Law, p 157, qualifying the principle as a constitutional one.

89 See T. Tridimas, The General Principles of EU Law, p 137. N. Reich, in The European Court of Justice, p 22; K. Gutman, The Constitutional Foundations, p 305 seq.; A. HartKamp, European Law, 
stating that, "[s]ubject to the principle of proportionality, limitations may be made only if they are necessary and genuinely meet objectives of general interest recognized by the Union or the need to protect the rights and freedoms of others'.

Whereas in some areas the principle of proportionality has been applied in accordance with a soft assessment criterion, ${ }^{90}$ the proportionality test has followed a stricter approach in the field of protection of fundamental rights. ${ }^{91}$ In this case, since the '70s, the European Court of Justice has introduced a three-steps test to assess whether: the measure (1) is suitable for the pursued objective; (2) it is necessary since no less restrictive measure would be equally adequate; (3) is proportionate (stricto jure) in the light of the circumstances surrounding the application of the measure. ${ }^{92}$

The proportionality of measures against violation of EU law is often imposed by EU consumer legislation. ${ }^{93}$ The principle should apply to all types of enforcement, whether public or private, including ADR, and to all the type of measures, whether injunctive, punitive, compensatory, etc. ${ }^{94}$ The duty to apply the principle to different types of remedies and enforcement systems is recognized by national enforcers but practices differ on its implications for remedies and sanctions on the basis of different traditions and procedural legislations. ${ }^{95}$ We adopt a functional approach to proportionality and suggest some criteria to define sanctions and remedies in consumer law considering the different functions in criminal, administrative, and civil enforcement.

p 116; S. WeatheriLl, Contract Law of the Internal Market (Cambridge: Intersentia 2016), p 201 seq.

90 Reference is to the so called 'manifestly inappropriate test', pursuant to which the EU measures would be considered disproportionate in respect of individual rights only if manifestly inappropriate. See T. Tridimas, The General Principles of EU Law, p 138.

91 See T. Tridimas, 'Proportionality in Community Law: Searching for the Appropriate Standard of Scrutiny', in E. Ellis (ed.), The Principle of Proportionality in the Laws of Europe (Oxford-Portland, Oregon: Hart Publishing 1999), p 66; C. Cauffman, 'The Principle of Proportionality and European Contract Law', in Rules and Principles in European Contract Law, pp 69-98; N. Reich, General Principles of EU Civil Law, p 86 seq., showing that reference to fundamental rights may influence both sides of the balancing assessment.

92 See ECJ 11 July 2002, C-210/00; see for further references and analysis, K. Gutman, The Constitutional Foundations, p 306.

93 See e.g. Art. 13 Dir. 2005/29/EC; Art. 23 Dir. 2008/48/EC; Art. 24 Dir. 2011/83/EU.

94 T. Tridimas, The General Principles of EU Law, p 456 seq. On proportionality as applied to ADR and ODR see Directive 2013/11/EU on ADR, recital (31), and UNCITRAL, Draft outcome document reflecting elements and principles of an ODR process, 22 December 2015, A/CN.9/ WG.III/WP.140, part. para. 9.

95 E.g. minimum and maximum amounts of fines for infringements vary quite radically across MSs, although made 'proportional' in respect of the gravity of the infrigement. 


\subsection{The Balancing Function of the Principle of Proportionality in the Judicial Dialogue Between the CJEU and National Courts}

28. Though less often than effectiveness, proportionality has been referred to by the CJEU to define the scope of consumers' remedies and the procedural requirements associated with them. ${ }^{96}$ National courts themselves have been engaged into a judicial dialogue based on the use of the principles, sometimes providing innovative solutions beyond the implications already drawn by the Court of Justice. ${ }^{97}$

In some cases, proportionality has been used by the CJEU to complement the principle of effectiveness and to somehow boost the level of consumer protection. Often the principle has been used to strike a balance between consumer rights protection and the interests of professionals or the general interest, like the one to a quicker settlement of disputes. When proportionality aims at balancing consumer's interests with other conflicting legitimate interests, the focus tends to be on procedural fairness (e.g. fair trial, fair allocation of procedural costs, reasonable length of the procedure, reasonable allocation of burden of proof, etc.) and on the effects and costs of the claimed remedy for the defendant (e.g. costs of repair or replacement), sometimes limiting the right to an effective protection as a not absolute right ${ }^{98}$ or striking a balance between right to an effective protection and right of defence. ${ }^{99}$ In these cases, proportionality requires that the remedy does not impose an unnecessary or excessive burden on the infringer compared to the benefits for the consumer. This burden is balanced against the objectives pursued through the remedy, with different implications depending on the individual or collective nature of the procedure at stake. As a consequence, in case of mass-harm situations, remedial costs for the infringer may well increase and still be proportionate given that the benefits refer to a large number of consumers. ${ }^{100}$

See N. ReICH, in The European Court of Justice, p 81; N. ReIch, General Principles of EU Civil Law, p 155; A. Hartкamp, European Law, p 116 seq.

97 See e.g. in the Italian case-law, Corte di cassazione (Joint Chambers) 13 September 2005, no. 18128, holding that, in the light of the principle of equity (principio di equità), the judge may $e x$ officio moderate an excessive penalty clause for the protection of a general interest in the contractual balance or in the adequacy of contractual penalties.

98 See e.g. Opinion of Advocate General Trstenjak delivered on 6 July 2010, VB Pénzügyi Lizing, Case C-137/08, para. 115, where the application of the principle of proportionality to the right to an effective protection leads to consider proportionate the duty of the court to guide, question and clarify the issue at stake and to 'direct the course of the proceedings', whereas disproportionate to abandon the principle of the active role of the parties in civil proceedings in favour of the principle of court-directed and court-investigated proceedings.

99 See e.g. CJEU 17 November 2011, Hypotećní banka a.s., C-327/10, paras 52-53, on the proportionate interference with the right of defence when the protection of the former would make meaningless the applicant's right to an effective protection, being the defendant's domicile totally unknown.

100 See e.g. Tribunale di Roma 17 April 2009, where the judge has deemed proportional an order requesting the professional to send a letter to all customers in order to inform them about the unfairness of a clause imposing undue costs for withdrawal. 
29. From a procedural point of view, the balancing function performed by the principle of proportionality may regard the allocation of the burden of proof and then lead to the use of presumptions when the effort to prove the harm or the amount of profits made out of the infringement would be disproportionate ${ }^{101}$; it may concern the scope of res judicata and then limit those in respect of the fair trial principle ${ }^{102}$; it may help balancing consumer protection with the general interest into a 'quicker and less expensive settlement of disputes (...) and a lightening of the burden on the court system' as accomplished by rules on mandatory out-of-court settlement procedures. ${ }^{103}$

30. From a substantive point of view, the balancing function of the principle of proportionality affects both the choice and the determination of civil remedies. ${ }^{104}$ This occurs not only when they address professional's infringements but also when they sanction a consumer's breach. In the former case proportionality is often applied to remedies in kind (such as repair, replacement or many types of corrective injunctions), therefore balancing the need to attain effective consumer protection against the costs incurred to operationalize the remedy, e.g. by removing and replacing a defective good already built-in within a complex construction. ${ }^{105}$ In the

101 Though also affected by proportionality, this balancing is more often grounded by courts on the principle of effectiveness. See CJEU 4 June 2015, C-497/13; Italian Consiglio di Stato, VI chamber, 17 November 2015, no. 5250. See also P. Hacker, 'One Size Fits All? Heterogeneity and the Enforcement of Consumer Rights in the EU After Faber', 12. ERCL (European Review of Contract Law) 2016(2), p (167) at 173); Italian Corte di cassazione 4 June 2015, no. 11564, FI (Foro italiano) 2015, p 2742.

102 Clearly in the perspective of proportionality as means to strike a balance between effective consumer protection and the professional's right to be heard, see Opinion of Advocate General Trstenjak delivered for the Invitel case (C-472/10) on 6 December 2011, para. 59, as recalled by the CJEU's judgment in the same case; Opinion of the Advocate General, C-119/15, para. 67 seq. In the perspective of effectiveness more than proportionality, see Polish Supreme Court, 20 November 2015 (Supreme Court III CZP 17/15).

103 See CJEU 18 March 2010, Joined Cases C-317/08, C-318/08, C-319/08 and C-320/08, para. 65. See also, more recently, the Opinion of Advocate General Saugmandsgaard Øe delivered on 16 February 2017, Menini \& Rampanelli, Case C-75/16, para. 82, considering the conditions stated in Alassini as relevant for assessing whether an obligation to have recourse to an ADR procedure complies with Art. 47 CFREU. Further to the Alassini judgment, Italian courts disagree on whether the consumer's claim, which is not preceded by an attempt of mediation, shall be declared inadmissible or merely stay the proceedings until mediation is run (see Corte di cassazione, 4 December 2015, no. 24711 for the latter position; Tribunal of Milano, sect. XI, of 24 September 2014 and 17 December 2015 for the former).

104 See e.g. CJEU 9 November 2016, C-42/15, para. 67 seq., where the Court has concluded that considering a consumer credit agreement as interest-free for failure to include mandatory information in the contract may represent a proportionate remedy only to the extent that the missed information may hinder the consumer's ability to assess the extent of his liability in the credit contract.

105 See with regard to repair and replacement of defective goods, CJEU 16 June 2011, Gebr. Weber GmbH v. Jürgen Wittmer, and Ingrid Putz v. Medianess Electronics GmbH, Joined Cases C-65/09 
latter instance, the principle has been used by the CJEU to assess, e.g. the fairness of penalty clauses against consumers ${ }^{106}$; in case of multiple penalties for different breaches of terms in the same contract, the balance is struck taking into consideration the hypothesis of simultaneous use of all penalties, although in practice the professional could decide to invoke only some of the clauses. ${ }^{107}$ The CJEU shows that proportionality mainly depends on the scope and function of the sanction or remedy to which it applies. The approach is mirrored by national courts' reasoning, when they distinguish between penalty clauses mainly aimed at discouraging parties' breach and liquidated damages clauses, in which the main purpose is to $e x$ ante agree on an estimate of losses from breach. ${ }^{108}$

31. In some cases, the balancing function of proportionality in the choice of remedies may generate a "remedial hierarchy'. ${ }^{109}$ When remedies are ranked along a hierarchy, the more lenient or more cost effective remedy shall be preferred to the more severe or more burdensome remedy insofar as it is effective. ${ }^{110}$ The seriousness of the infringement, on the one hand, and the cost-effectiveness of the remedy, on the other hand, represent the main criteria to design the hierarchy in conformity with principle of proportionality. Indeed, complementarily to the principle of effectiveness (more focused on the victim's interests), the principle of

and C-87/09. Proportionality of corrective measures is also relevant in other sectors, such as for the enforcement of intellectual property rights (see Art. 10 Dir. 2004/48).

106 See CJEU 30 May 2013, C-488/11.

107 See CJEU, C-377/14 and the Opinion of Advocate General Sharpston delivered on 19 November 2015 in the same case.

108 Unlike in the latter case, in the former instance proportionality may depart from the mere consideration of occurred losses in order to attain an effective dissuasive function. Indeed, when the clauses at stake mainly play the function of damages' liquidation, proportionality mostly leads to compare liquidated damages with damages which have been concretely occurred. See e.g. Tribunale di Sulmona, 25 February 2011, where the judge observes that a clause obliging the consumer to pay almost EUR 7000 for abuse use of a home broadcast service whose yearly fee remains below EUR 600 is definitively excessive and disproportionate, nor it may find any ground on clear and justifying criteria. By contrast, the Amsterdam Court of Appeal (judgment of 20 November 2012, ECLI:NL:GHAMS:2012:BY6370 (A/Eigen Haard)) deemed proportionate, in the light of Art. 6:233 Dutch Civil Code, an EUR 4,500 penalty clause for illegal subletting included in a tenancy contract having regard to its deterrence function. In a broader perspective, see also B. PASA, "The European Law of "Contractual Penalties", ERPL (European Review of Private Law) 2015(3), pp 355-384.

109 On the hierarchy of civil remedies in the light of the principle of proportionality, see F. CAFAGGI, 'The Regulatory Functions of Transnational Commercial Contracts. New Architectures', 36. FJIL (Fordham Journal of International Law) 2013, p 1557 seq.

110 F. Cafaggi \& P. Iamiceli, 'Contractual Relationships in Global Supply Chains: The Role of Cooperative Remedies', in ULR (Uniform Law Review) 2015, pp 135-179; with main regard to the Italian law of contractual remedies: P. IAmicelI, 'Diritto dei contratti, principio di proporzionalità e tutele contro l'inadempimento', AC (Annuario del Contratto) 2014 (Torino: Giappichelli 2015), p. 27 seq. 
proportionality often tends to rebalance the remedial equilibrium taking the infringer's interests and costs into account. ${ }^{111}$

\subsection{Criteria to Assess Proportionality: A Functional Approach}

32. Whereas the principle of proportionality shall be applied to different types of measures, the modes and effects of application largely depend on (1) the nature of the specific measure, (2) its function, and (3) the type of enforcement. Thus, in the area of monetary measures (e.g. fines, damages, restitutions, price reduction, etc.) proportionality mainly should affect the amount of the sanction or the remedy. ${ }^{112}$ By contrast, in respect of other types of measures, it influences the grounds and modes of remedies' application as well as their effects, leading the judge to distinguish between interim measures and final injunctions, partial and total contract invalidity, partial and total contract termination, etc. Moreover, whereas in case of punitive (penalty-like) measures, proportionality most commonly defines the remedy in respect of the gravity of the infringement and its effects, the proportionality of compensatory and restitutionary remedies tends to refer primarily to the consequences suffered by the victim. Hence, even within monetary remedies significant differences in the application of the principle of proportionality emerge between fines, restitution and damages. In the former the focal point is the infringer, in the latter the focal point is the injured consumer. ${ }^{113}$

In the domain of sanctions, the main factor is often considered the gravity of the infringement. ${ }^{114}$ This approach is spelled out for criminal enforcement in Article 49(3), CFREU, stating that 'the severity of penalties must not be disproportionate to the criminal offence'. ${ }^{115}$ It applies also to administrative and civil penalties but it is balanced with other factors as the magnitude of consequences, the nature, personal or economic, of interests of the injured, the duration and the repeat nature of the infringement.

111 Art. 3 Directive 44/99 on consumer sales goods and guarantee is a good example of remedial hierarchy. See CJEU 16 June 2011, Joined Cases C-65/09 and C-87/09. See S. Grundmann, 'Consumer Sales - The Weber-Putz Case-Law: From Traditional to Modern Contract Law', in Landmark Cases of EU Consumer Law, pp 725-742; C. Cauffman, in Rules and Principles, p 69 seq.

112 The undertaking shall then be enabled to bring proceedings to challenge the fine's proportionality (see CJEU 21 December 2016, C-119/15, para. 45).

113 As we see below this distinction is not without exceptions and does allow for contaminations of criteria (see below footnote n. 120 and 121 and text). However, it does impinge on western legal traditions as often mirrored into Constitutions and statutory acts. At the EU level, see, for criminal sanctions, Art. 49(3) CFREU; for damages, see Art. 3 Directive 2014/104/EU on the principle of full compensation of harm caused by infringements of competition law and the ban against overcompensation 'whether by means of punitive, multiple or other types of damage' (Art. 3.3).

114 See e.g. ECJ 16 December 1992, C-210/91, where further references are provided.

115 See among others, with regard to competition law infringements, General Court 29 February 2016, Schenker Ltd v. European Commission, T-265/12, para. 245 seq. 
33. This functional approach to the application of the principle of proportionality largely explains why it might require different metrics depending on the type of enforcement and their characteristic objectives, whether preventive, compensatory or sanctionary. E.g. within administrative enforcement, where deterrence has been considered a priority, sanctions are often adjusted against the size of the infringer (defined by the amount of revenues), the seriousness of the violation, the magnitude of the conduct's consequences in order to attain an adequate deterrent effect. ${ }^{116}$ Indeed, size of the infringing enterprise may represent a proxy for the benefits resulting from the violation often hard to determine. ${ }^{117}$ In case of remedies aimed at preventing future infringements or correct the consequences of committed violations (injunctions, corrective measures, acceptance of infringer's offer of corrective commitments), proportionality may apply differently depending on whether the enforcer issues an injunctive order or accepts as binding the commitment proposed by the infringer. Indeed, in the former instance the measure has also to ascertain the infringement, whereas in the latter it needs to provide a more rapid solution to the problems identified by the enforcer without a formal finding of an infringement: in both cases proportionality will relate to the cost and adequacy of order/commitment to address the concerns at stake, whereas in the former proportionality should also be adjusted against the gravity of the infringement. ${ }^{118}$ In judicial or private enforcement

116 See CJEU 16 April 2015, C-388/13, para. 58, where the CJEU has given a clear indication of proportionality of sanctions in unfair commercial practices, having special regard to the 'frequency of the practice complained of, whether or not it is intentional, and the degree of harm caused to the consumer.' This approach is mirrored by case law at national level. E.g. when sanctioning unfair commercial practices, the Italian Competition Authority adjusts fines against the following criteria, as provided by Art.11 law 689/81, as referred to by Art. 27(13), Consumer Code: the gravity of the violation, the measures taken by the infringer to reduce or eliminate the consequences of the infringement, the position of the acting person, the economic conditions of the infringing enterprise (see e.g. Decision no. 25701, 25 November 2015, Eni s.p.a.; Decision no. 26019, 11 May 2016, Eni s.p.a.; Decision no. 26137, 4 August 2016, Volkswagen s.p.a.). See also Arts 47-48 Hungarian Consumer Protection Act, providing that amount of fine for unfair commercial practices shall be calculated upon the net income of the trader, and it shall also take into account the possibility of harming consumer health and the possible injury of the large public; moreover a discount is applied to SMEs (see V. BaLogh \& K. J. Cseres, 36. JCP 2013, p 358 ).

117 See e.g. the Italian judgment of the Consiglio di Stato in the case $A G C M$ v. Telecom Italia, 5 March 2015, no. 1104, comparing the fines applied by the Competition Authority to two communication services providers and assessing their proportionality in respect of either infringer's size.

118 This distinction may be derived from competition law and particularly from the CJEU's jurisprudence concerning the application of the principle of proportionality, respectively, to Art. 7 (on injunctions) and 9 (on commitments) Reg. 1/2003, the former expressly referring to proportionality. See part. ECJ 29 June 2010, Alrosa, C-441/07 P, paras 38-41, on the different assessment of proportionality in respect of injunctions and commitments. For an application in Italian case law, see Consiglio di Stato, 22 September 2014, no. 4773. For the relevance of gravity of infringement in the proportionality assessment of corrective measures see also Art. 10(3) Dir. 
proportionality may take into account the economic or non-economic nature of the harm, the number of consumers affected, the duration and, to some extent, the costs of the different remedies borne by the injurer.

At the same time, it should be acknowledged that metrics to assess proportionality may be re-combined across different types of enforcement. ${ }^{119}$ Hence, for instance, public enforcement measures, that are mainly aimed at sanctioning, may take the amount of losses into account, ${ }^{120}$ or remedies normally aimed at making consumer's losses whole, may be adjusted against the gravity of the infringement or the bad/good faith of the infringer. ${ }^{121}$

Indeed, criteria normally used to ensure proportionality of public enforcement measures may become concurrently relevant for private enforcement when similar functions are performed, such as deterrence. ${ }^{122}$ The analysis below will present some illustrations in order to show the role of the principle of proportionality in sanctioning within the dialogue between courts and legislators.

2004/48, on enforcement of intellectual property rights (see: Opinion of Advocate General Wathelet delivered on 20 November 2014, Huawei Technologies Co. Ltd v. ZTE Corp., C-170/ $13)$.

119 See below, s. 5 .

120 See in the area of unfair practices, CJEU 16 April 2015, C-388/13. See also, in the Italian case law, Consiglio di Stato, Joint Chambers, 25 June 2014 no. 15, which applies Art. 614-bis Italian Code of civil Procedure, regulating the amount of astreintes with regard to foreseeable or liquidated loss among other criteria.

121 See e.g. the UK regulation unfair commercial practice and the remedy of price reduction therein provided: although it could be considered as more compensatory than penalty, the legislator introduces metrics based on the gravity of the infringement. See below, footnote 123 and corresponding text. More could be added if one takes into account literature and practices on punitive damages. See C. Vanleenhove, 'Punitive Damages and European Law: Quo Vademus?', in L. Meurkens, E. Nordin (eds), The Power of Punitive Damages - Is Europe Missing Out? (Cambridge-Antwerp-Portland: Intersentia 2012), pp 337-353. For a recent discussion in Italian jurisprudence, see C. Scognamiglio, 'Principio di effettività, tutele civile dei diritti e danni punitivi', RCP (Responsabilità civile e previdenza) 2016, p 1120B seq., also in respect of Corte di cassazione 16 May 2016, no. 9978.

122 A wide concept of deterrence is here used as aimed at discouraging infringements by threatening the use of sanctions or neutralizing the effects of misbehaviour. See below, s.4, also in relation to the concept of dissuasiveness. This wide concept does not aim at overshadowing the functional differences of deterrence with respect to the several remedies it may relate to. E.g. the function of deterrence concerning injunctions is specifically aimed at bringing the infringement to an end or preventing its future occurrence, whereas the deterrence effects of damages will depend on the aptness of such monetary compensation to influence future behaviour. See R. Shavell, 'The Optimal Structure of Law Enforcement', 36. JLE (Journal of Law and Economics) 1993(1), pp 255-287; R. Shavell, 'The Advantage of Focusing Law Enforcement Effort', 24. IRLE (International Review of Law and Economics), 2004 pp 209221. 


\subsection{Proportionality of Civil Remedies and the Dialogue Between Legislators and Courts}

34. The principle of proportionality has relevant potentials when examined in the light of recent consumer reforms occurred at national level. Sometime the national legislator has incorporated a proportionality assessment into civil remedies (e.g. price reduction) which links the amount of the monetary remedy to the gravity of the infringement. ${ }^{123}$ In other cases, the law has been less specific leaving room for a judicial discretionary power in defining the civil remedy, for which principles (and, more particularly, the principle of proportionality) may play an important role.

For example, Article VI.38 of the Code of Economic Law, recently adopted in Belgium, provides for a specific remedy against unfair commercial practices enabling a consumer to claim reimbursement of the amount paid or to refuse payment without any duty to return goods or compensate services enjoyed under the contract. ${ }^{124}$ Whereas in seven specific cases the consumer's right to retain goods and services without payment is automatic, in all the other possible cases the remedy is awarded upon discretion of the court. ${ }^{125}$ This discretion may lead to apply a 'non-payment' rule, a partial payment rule or a right to return the goods (a sort of right to termination) depending on the severity of the infraction, the extent to which the consumer's decision has been influenced by the unfair practice, the financial consequences and the suffered harm for the consumer: in cases like this one, the principle of proportionality may play an important role in guiding the judge's assessment. ${ }^{126}$ Indeed, national courts may (and should) refer to EU principles whenever the law vests the judge with the power to identify or tailor the civil remedy to the specific circumstances being the remedy not univocally determined in the law. ${ }^{127}$ As it is always the case when general principles are applied, national legal systems may differ and it is for judicial dialogue between national and European Courts to ensure that applications do not excessively diverge.

123 See UK Consumer Protection (Amendment) Regulation 1999 (CPAR 2014), modifying the Consumer Protection from Unfair Trade Regulation (CPUTR) 2008, Art. 27L(1), vesting the consumer suffering from an unfair commercial practice with a right to a discount whenever the consumer has exercised his right to unwind the contract, and Art. 27I(4), regulating the amount of discount. See J. Devenney, JECML 2016(2), p 100 seq.

124 R. SteEnnot, ERPL 2015, p 188 seq.

125 Among the former are: falsely claiming that a product is able to cure illness; creating the false impression that the consumer has won or will win a price; demanding immediate payment for products supplied by the undertaking but not solicited by the consumer (inertia selling).

126 In this perspective: R. STEEnnot, ERPL 2015, p $189 \mathrm{f}$.

127 This could be, e.g. the case when the court is requested to determine the content of an injunction pursuant to Art. 2 Dir. 2009/22/EC. 


\subsection{Concluding Remarks on Proportionality}

35. Though less often used than the principle of effectiveness, proportionality plays an important role in the adjudication of consumer litigation balancing the need to ensure effective protection and the urge to avoid any excessive or unnecessary burden that such protection may create, especially on other fundamental rights. The role of proportionality becomes even more prominent when different remedies (e.g. injunctive remedies and damages) or different types of enforcement (e.g. private and public enforcement) coexist. ${ }^{128}$

To sum up, proportionality is used by courts (1) to identify the appropriate procedure and measure, with different degree of discretion depending on the existence or not of a legal hierarchy, and (2) to tailor procedures and measures to the concrete circumstances. To state (2) in very general terms, proportionality aims at balancing costs (procedural costs and remedial costs) and benefits of remedies. This balance varies in administrative and judicial enforcement leading to different patterns. Proportionality helps controlling the discretion of enforcers when deciding appropriate and effective sanctions and remedies. When the main purpose is to make the consumer whole, the focus is on the consequences of the violation; if enforcement is mainly aimed at sanctioning, proportionality tends to take into account the infringer's behaviour in terms of gravity, fault or intention and repeatedness. As we see below, deterrence may impinge on both functions (compensatory and sanctionary) and enriches the proportionality test by looking at the benefits that may be obtained from the infringement, for which the size of the business may represent a proxy.

36. The principle of proportionality may lead the court to identify the appropriate procedure and remedy when more options are available and discretionary power needs to be adjusted against the objective pursued; in some instances, this assessment leads to the identification of remedial hierarchies, in which the access to certain (more disruptive) remedies becomes available only if other (more lenient) remedies are unsuccessfully used or may not be used. Not always these hierarchies are defined in legislation; judicial dialogue, as fostered by the use of principles, may lead to identify remedial hierarchies. Indeed, whereas national legislation often regulates enforcement mechanisms taking proportionality into account, large room for discretionary judicial powers exist calling for an important application of the principle of proportionality.

As a consequence, applications of proportionality to remedies may expand well beyond the current national legislation on civil remedies for consumer protection. For example, (1) proportionality of injunctions issued by courts could itself be adjusted against the gravity of violation, the nature and extent of incident's consequences and, especially when injunctions impose to correct misbehaviours, the

128 See s. 5 below. 
costs of such correction ${ }^{129} ;(2)$ the size and economic conditions of the infringing enterprise could be referred to when deciding about the alternative between repair of defective goods and contract termination ${ }^{130} ;(3)$ the proportionality of price reduction or restitution could be adjusted against the gravity of the infringement to improve deterrence ${ }^{131} ;(4)$ the spontaneous adoption of corrective measures by the infringer, as often taken into account in public enforcement, could also contribute to ensure proportionality of civil remedies such as replacement or price reduction. ${ }^{132}$ Vice versa, (5) the enforcer's acceptance of infringer's commitment to reduce or eliminate the consequences of violation could be considered disproportionate when violations show gross negligence or intention to harm. ${ }^{133}$ In fact, current legislation only occasionally articulates similar metrics, whereas national enforcers and, more particularly the courts, need guidance to explore the several avenues opened by the principle of proportionality.

\section{The Principle of Dissuasiveness}

37. Dissuasiveness can influence (1) the choice of enforcement (e.g. administrative v. judicial), (2) the content of the remedy, (3) the combination of remedies, (4) the sequencing of remedies, and (5) the definition of a hierarchy among them. Judicial dialogue has had a clear impact on the first, third and

129 The gravity of infringement influences the availability of injunctive remedies in competition law (Art. 7 Regulation 1/2003) and in the corrective enforcement of intellectual property rights (Art. 10(3) Dir. 2004/48/EC, see footnote above 118). In the area of consumer law, although Directive 2009/22/EC does not provide for a similar criterion, it emerges in some MS's legislation (see with regard to Hungary, M. OgonzAŁEк, The Action for Injunction in EU Consumer Law, Doctoral Thesis, EUI, 2014, 30).

130 L\&E literature on contract termination helps to assess the proportionality of this severe remedy against the consequences borne by the defendant in respect of specific investments and access to market, as both affected by the size of the firm and its economic conditions (see M. ARTigot I Golobardes \& F. Gòmez Pomar, 'Long-Term Contracts in the Law and Economics Literature', in G. De Geest (ed.), Contract Law and Economics. Encyclopedia of Law and Economics (Cheltenham: Elgar, 2nd edn 2011), p 314 seq.

131 For an example, see the provision recently introduced in the UK law, as referred to above, in footnote n. 123(152).

132 The seller's ability to adequately repair a defective good is relevant to assess proportionality of price reduction and termination under Art. 3(5) Dir. 44/99, when repair has been (unsuccessfully) claimed by the consumer. An extensive interpretation of this provision could support a similar criterion when repair is deliberately offered by the seller.

133 The assessment of infringer's commitment to stop and correct her conduct is normally addressed within public enforcement mechanisms. See e.g. Art. 9(2)(c) Italian Competition Authority's Decision 1 April 2015, no. 25411 (Regulation on procedures in the field of consumer protection against misleading advertisement, unfair commercial practices, discrimination, unfair terms), establishing that the Authority shall reject the infringer's offer of commitments in case of gross and undisputable violation. 
fifth dimension, reshaping enforcement of both administrative authorities and judicial bodies. Here, the primary focus is on private enforcement and civil remedies but clearly the dissuasive strength is influenced by the combination of private, administrative, and criminal enforcement when they operate contextually.

The CJEU has provided definitions of what does or does not constitute a dissuasive penalty. ${ }^{134}$ However, a general definition of dissuasive measures applied to different types of sanctions, e.g. damages, fines, injunctions, restitution, is still missing. ${ }^{135}$ We offer a systematic framework concerning the dimensions upon which dissuasiveness plays a role and the variables to be considered when evaluating it.

38. The dissuasive effects of any consumer remedy and/or sanction will largely depend on the probability of being detected, which in turn depends on the enforcement system in place. ${ }^{136}$ The growth of administrative enforcement and the use of administrative sanctions of criminal nature as a complement to private enforcement may be interpreted as a signal of the difficulties to detect and deter wrongful behaviour in the area of private enforcement where the costs of monitoring is borne by the injured. ${ }^{137}$

134 See for example CJEU 10 September 2014, Kušionová, C-34/13, paras 59-60; CJEU 30 May 2013 , C-488/11, para. 58; CJEU 27 March 2014, LCL Le Crédit Lyonnais SA, C-565/12, paras 50 seq.; CJEU 9 November 2016, C-42/15.

135 In L\&E literature general (or market) deterrence has been distinguished from specific deterrence in order to highlight the role that both market transactions (in the former case) and the law (in the latter case) may play in balancing costs and benefits of potentially dangerous activities and thus defining the optimal level of deterrence. Indeed, a potential tortfeasor may tradeoff the benefits coming from the offending activity against the costs imposed to him through a liability rule (general or market deterrence) or the law may impose a stricter rule that prevents the potential tortfeasor from engaging in that activity beyond a given threshold which is defined by law as the maximum acceptable level by the society (specific deterrence). See G. CALABresi, The Costs of Accidents (New Haven: Yale University Press 1970), p 103 seq.

136 Opinion of Advocate General Kokott, delivered on 14 October 2004, joined cases C-387/02, C-391/02 and C-403/02: 'What is decisive in this regard is not only the nature and level of the penalty but also the likelihood of its being imposed.' The chance of detection is largely debated as one of the assessment criteria for optimal sanctions. Many more are debated in the L\&E literature well beyond the scope of this article. See GarY S. BEcker, 'Crime and Punishment: An Economic Approach', 76 J. Pol. Econ. (Journal of Political Economy) 1968, p 169; A. M. Polinsky \& S. Shavell, 'The Optimal Tradeoff Between the Probability and Magnitude of Fines', 69 Am. Econ. Rev. (American Economic Review) 1979, p (880) at 883; R. Craswell, 'Damage Multipliers in Market Relationships', 25. JLS (The Journal of Legal Studies) 1996, pp 463-492.

137 F. Cafaggi \& H.-W. Micklitz, 'Collective Enforcement of Consumer Law: A Framework for Comparative Assessment', ERPL (European Review of Private Law) 2008(3), pp 391-425; F. Weber \& M. Faure, 23. ERPL 2015, p 529. See also R. Steennot, ERPL 2015, arguing for the need of public enforcement of unfair terms legislation in relation to the lack of use of private enforcement mechanisms due to their costs and consumers' ignorance. 
39. Dissuasiveness has also an impact on the relationship between individual and collective enforcement. At times small or negative value claims are hard to detect and litigate individually but when aggregated they can be cost-effectively sanctioned. The choice of enforcement mechanisms, based on the principle of dissuasiveness, may look at its aptness to address mass-harm situations producing erga omnes effects, which is mostly (but not exclusively) the case for public enforcement measures.

40. Within each type of enforcement, dissuasiveness may influence the choice of remedies and their content. For instance, monetary remedies (such as damages, price reduction, restitution, civil penalties, etc.) may be more easily perceived as 'prices' and therefore 'traded' against the benefits that a specific infringer may derive from a potentially harmful activity. ${ }^{138}$ Injunctions or remedies in kind like repair or replacement may in principle more easily escape this risk. Most often, compensatory damages have little deterrent effects. ${ }^{139}$ They should be combined with other remedies (injunctions) or administrative sanctions (fines) to dissuade the potential infringer. Moreover, some remedies may be less dissuasive to the extent that they more easily induce infringers to take strategic precautions to reduce the likelihood of a consumer claim. ${ }^{140}$ Hence, in theory the principle of dissuasiveness suggests using remedies in kind rather than monetary remedies and punitive rather than purely compensatory measures. The principle of dissuasiveness applies to the sanctions and remedies directly regulated by EU legislation and, within the boundaries of national procedural autonomy, to those connected, like for example restitution in the case of unfair contractual terms. ${ }^{141}$

Dissuasiveness of damages concerns the boundaries between compensatory and punitive damages. Should punitive damages be introduced in order to

138 See R. Cooter, 'Prices and Sanctions', CLR (Columbia Law Review) 1984, pp 1523 seq.; U. Gneezy-A. Rustichini, 'A Fine Is a Price', JLS (Journal of Legal Studies) 2000, p 1 seq.

139 So for liquidated damages clauses, having a prior compensatory function, as compared with penalty clauses, having a prior deterrent function. See H. BEale, 'Penalty Clauses in English Law', ERPL (European Review of Private Law) 2016(3)(4), p 353 seq., commenting on English case law with a view to the then forthcoming decision of the Supreme Court in the Cavendish case with special regard to the issue of whether the deterrent function a contractual clause on penalties for breach may be 'economically justifiable' and therefore enforceable under English law.

Neither the text or this footnote deny that damages may have a deterrent function and that this function may even be prevalent in some instances. See the recent judgments in the Italian jurisprudence: Constitutional Court 23 June 2016, no. 152; Corte di cassazione 16 May 2016 no. 9978. On the 'dissuasive' function of damages in consumer protection see D. PoelzIG, in The European Unfair Commercial Practices Directive, p 241.

140 For example, in the case of the Belgian legislation enabling the consumer to refuse price payment and retain the goods or services received when the consumer has been victim of an unfair commercial practice (see above) may quite easily induce professionals to ask for advance payments, whose return will represent a much weaker remedy for the consumer than the payment refusal.

141 See CJEU 21 December 2016, Joined Cases C-154/15, C-307/15 and C-308/15, paras 64-70. 
make monetary measures dissuasive? CJEU has been reluctant to take this path and the EU legislator has explicitly excluded punitive damages in the field of consumer redress for competition law infringements. ${ }^{142}$ The issue goes beyond consumer legislation and concerns many areas: from non-discrimination to intellectual property rights. ${ }^{143}$ Outside damages, monetary sanctions are used to punish non-compliance with injunctions both by administrative and by courts.

41. Unlike effectiveness dissuasiveness looks primarily at the infringer and it might be correlated to various factors ${ }^{144}$ : (1) the seriousness of the infringement, (2) the injurer's state of mind (intent, recklessness, fault), ${ }^{145}(3)$ the magnitude of the potential harm, (4) the type of interests (economic or non-economic), (5) the past behaviour of the injurer, (6) the probability of detection. ${ }^{146}$ Functionally, dissuasiveness may have a deterrence or a punishment function. Often, however, it is a matter of degree. The content of the remedy, for example the amount of the fine or the duration of the injunction, may focus on deterrence up to a certain level. Beyond that level the punishment becomes the main objective.

42. Dissuasiveness includes deterrence but goes beyond. Not only it discourages infringements by threatening the use of sanctions or neutralizing the effects of misbehaviour. But it also uses signalling and reputational tools in order to encourage compliance. Reputational sanctions like black lists of firms that have violated the law may have a strong dissuasive effect. The use of private regimes like industry

142 See Art. 3(3) Directive 2014/104/EU.

143 See in the field of non-discrimination CJEU 17 December 2015, C-407/14 and, in the field of intellectual property rights, 25 January 2017, C-367/15. According to CJEU, Art. 25 Directive 2006/54/EC in the field of non-discrimination allows MS to introduce punitive damages in this field.

144 See e.g. the Italian 1. 689/81, on the determination of administrative sanctions (also applicable to consumer violations), in respect of the following factors: the gravity of the violation, the measures taken by the infringer to reduce or eliminate the consequences of the infringement, the position of the acting person, the economic conditions of the infringing enterprise.

145 Whether this state of mind affects the determination of applicable remedies substantially depends on the type of enforcement and the applicable regime. E.g. civil, administrative and criminal liability may differ under this respect. See e.g. the Italian 1. 689/81, establishing that administrative liability occurs when acts or omissions are voluntary and either negligent or intentional (Art. 3). See also Art. 106 (1.4) Polish Competition and Consumer Law, establishing a penalty for business practices that harm consumers' collective interests, though enacted involuntary. Negligence may be presumed (see e.g. in Italian case law, Corte di cassazione no. 5894/2007, identifying a presumption of fault when an administrative violation occurs). Even when intentionality is not a prerequisite for a sanction to be applied, it can influence its intensity. See, expressly referring to the principle of dissuasiveness, Administrative Tribunal of Lazio Region, 9 September 2015, no. 11122, PS9467 - H3G Servizi Premium; Id., 10 November 2015, no. 12707, PS9524; Id., 10 November, 2015, no. 12709, PS9082 - San Carlo Patatine Light).

146 See footnote $\mathrm{n} .123,136$ above and corresponding text. 
codes can be combined with the more traditional deterrent measures. Even forms of cooperative enforcement may have dissuasive effects. The approval of voluntary commitments taken by the infringer in order to repair and correct the effects of violation may dissuade it from future infringements much more effectively than the threat of the payment of a fine, which may be perceived as a 'price' for the opportunity to infringe. The injunction claimed by a consumer association or filed against an industry organization may have a much higher impact than a remedy adopted within an individual procedure; by looking at collective effects of individual infringements, trade organizations may themselves discourage violations and provide instructions for appropriate compliance. More than deterrence, mainly based on a rational economic reasoning, dissuasiveness looks at behavioural choices in their more complex dynamics, including learning practices, signalling, reputational effects. ${ }^{147}$

43. In very general terms, when the EU legislator establishes that Member States have to provide dissuasive remedies against infringements of EU consumer law, these remedies shall either promptly prevent the infringement or its continuation or, when they operate ex post, substantially deprive infringers of the benefits expected from the infringement. Dissuasiveness focuses on the incentives of the infringer and tries to dissuade the infringer by making the infringement not profitable. Moving from this perspective, not only injunctions ${ }^{148}$ but also invalidity rules and restitutionary remedies play an important role since infringers' expected benefits often find their legal grounds in consumer contract terms. ${ }^{149}$ The CJEU has reaffirmed the importance of restitutionary obligations connected with invalidity and the application of the principles. Restitution of profits or restitution of interests may have dissuasive effects. ${ }^{150}$

147 G. Jolls, G.R. Sunstein \& R. Thaler, 'A Behavioral Approach to Law and Economics', 50. SLR (Stanford Law Review) 1998, p 1471. Among other behaviouralist doctrines, the social learning theory has long influenced the debate on crime punishments; see R.L. AKERS, 'Criminology: Rational Choice, Deterrence, and Social Learning Theory in Criminology: The Path Not Taken', 81 JCLC (Journal of Criminal Law and Crimonology) 1990, p 653.

148 On the intrinsically dissuasive nature of injunctions, see CJEU 26 April 2012, Nemzeti Fogyasztóvédelmi Hatóság v. Invitel Távközlési Zrt, C-472/10, paras 37-38. On the role of astreintes combined with injunctions to increase their dissuasiveness see the Report from the European Commission concerning the application of Directive 2009/22/EC of the European Parliament and of the Council on injunctions for the protection of consumers' interest, Brussels, 6 November 2012, $\operatorname{COM}(2012) 635$ final, part. 13.

149 The combination between non-bindingness and orders to desist from executory procedures launched on the basis of unfair terms reaches a high degree of dissuasiveness (and effectiveness) in the perspective of the CJEU. See CJEU 10 September 2014, C-34/13, para. 60.

150 On the dissuasive effect of restitution see CJEU 21 December 2016, Joined Cases C-154/15, C307/15 and C-308/15, para. 63, where the court recognizes the dissuasive effects of restitution and declares the limitation of banks restitution duties to the time of the Tribunal Supremo judgment against EU law, in particular contrary to the directive 93/13. 
44. The CJEU has attached to contractual terms' invalidity an important dissuasive function. ${ }^{151}$ This is true for unfair contractual terms but also for unfair trade practices that translate into contractual invalidity. ${ }^{152}$ Rejecting the option of removing all contracts from the market just because they are means to violate EU law, the Court has supported the use of partial non-bindingness, i.e. non-bindingness of the specific term violating the law. ${ }^{153}$ Moreover, on the basis of the principle of dissuasiveness, it has held that the national judge should refrain from replacing an unfair term with a fair one, since the potential infringer would then be induced to take the risk of a later judicial modification rather than giving up the extra-benefits of an unfair term. ${ }^{154}$ This conclusion holds true if the term's invalidity does not unwind the entire contract. A different hypothesis would occur only if the term's non-bindingness regulates a core aspect of the contract transaction so that the whole contract would collapse were the term declared non-binding without being replaced. ${ }^{155}$

When applied to excessive penalty clauses imposed by professionals in consumer contracts, the CJEU's argument has stated the inapplicability of national contract law rules enabling the judge to reduce excessive penalty clauses. ${ }^{156}$ When the penalty for consumer is too high, the non-bindingness of the contractual term results in no penalty at all. National case law jurisprudence has mostly followed this

151 See the Opinion of Advocate General Trstenjak delivered on 6 December 2011, C-472/10, para. 57, as recalled by the CJEU's judgment in the same case. See also Opinion of the Advocate General, C-119/15, paras 71, 73 .

152 For a general study see A. RENDA et al., Study on the Legal Framework Covering Business-toBusiness Unfair Trading Practices in the Retail Supply Chain, Final Report, prepared for the European Commission, DG Internal Market DG MARKT/2012/049/E, February 2014, http:// ec.europa.eu/internal_market/retail/docs/140711-study-utp-legal-framework_en.pdf. For a more specific analysis see H.W. Mickuitz, in The European Unfair Commercial Practices Directive, p 177 seq. See CJEU 16 April 2015, C-388/13.

153 See part. Opinion of Advocate General Trstenjak delivered on 29 November 2011, C-453/10, para. 67. See also G. Tomás, 'Utile per inutile non vitiatur: can favor contractus be considered a European regula iuris?', 12. ERCL (European Contract Law Review) 2016(3), p 259 seq.

154 See CJEU 14 June 2012, C-618/10, para. 66 seq.; CJEU 9 November 2016, Home Credit Slovakia a.s., C-42/15. See on this topic: G.D’Amico \& S. Pagliantini, Nulità per abuso ed integrazione del contratto (Torino: Giappichelli 2015); E. NAvarretta, RDC 2016(5), p 1262.

155 See CJEU 30 April 2014, Árpad Kásler, C-26/13, paras 80 and 82. See R. Steennot, ERPL 2015, p 600 seq.; M. Dellacasa, 'Judicial Review of 'Core Terms' in Consumer Contracts: Defining the Limits', 11. ERCL (European Contract Law Review) 2015(2), pp 152-176. For an analysis on the waving impact of this EU jurisprudence on the Hungarian case law see M. Józon, 'The Methodology of Judicial Cooperation in Unfair Contract Terms Law', in Judicial Cooperation in European Private Law, p 129.

156 See CJEU 30 May 2013, C-488/11. This jurisprudence would make unavailable the general remedy of judicial reduction of excessive penalty clauses, provided, e.g. in the French and Italian legal systems. See M. Cannarsa, 'Penalty Clauses in French Law', ERPL (European Review of Private Law) 2015(3), p 297 seq.; F.P. PATTI, 'Penalty Clauses in Italian Law', ERPL (European Review of Private Law) 2015, p (309) at 317 seq.; with reference to Italian Corte di cassazione 24 September 1999, no 10511, see G. Vettori, 'The Fair Contract', ERCL 2016, p 6. 
reasoning, ${ }^{157}$ whereas some national courts and scholars have taken a different view, especially when term's replacement may in fact occur by means of application of default legal rules. ${ }^{158}$

\section{How Do the Principles Influence the Combination of Enforcement Systems?}

45. According to the principle of procedural autonomy enforcement of EU law is primarily a duty of MSs, which have to select the best enforcement mechanisms' mix to ensure EU law effectiveness. Consumer law is usually enforced at national level through a combination that includes criminal, civil, and administrative enforcement and, often, mandatory or voluntary ADR. ${ }^{159}$ In theory, these can be alternative systems but in practice they coexist. They perform different functions complementing each other. ${ }^{160}$ Complementarity may concern functions or, within the same function, different sanctions and remedies, pursuing the same or similar objectives. ${ }^{161}$ For example, complementary enforcement mechanisms may integrate deterrence and compensation or collective and individual consumer protection. $^{162}$

The choice of enforcement and their combination by MS must comply with fundamental rights and general principles like the right to effective judicial

157 See the follow-up decision of the Asbeek case: Court of Appeal Amsterdam, judgment of 29 July 2014 (ECLI:NL:GHAMS:2014:5414). See also, in the Italian case law, Corte di Appello di Milano 23 July 2004, Soc. Studio Opera C. G.S; Tribunale di Pescara 16 April 2016, which quotes the judgments by the CJEU in C-618/2010 and C-418/2011.

158 See the Italian Banking and Financial Arbiter (ABF) in the decision of 23 May 2014 following the CJEU's argument.

159 See C. Hodges, 'Fast, Effective and Low Cost Redress: How Do Public and Private Enforcement and ADR Compare?', in B. Rodger (ed.), Competition Law Comparative Private Enforcement and Collective Redress Across the EU (Dordrecht, NL: Kluwer 2014), p 255 seq.; Id, 'Consumer Redress: Implementing the Vision', in Pablo Cortés (ed.), The New Regulatory Framework for Consumer Dispute Resolution (Oxford: Oxford University Press 2016); F. Weber, 'Is ADR the Superior Mechanism for Consumer Contractual Disputes? - an Assessment of the Incentivizing Effects of the ADR Directive', 38. CP (Consumer Policy) 2015, pp 265-285. See also European Parliament, 'The Implementation of the Mediation Directive', 29 November 2016, http://www. europarl.europa.eu/thinktank/en/document.html?reference=IPOL_IDA(2016)571395, proposing a methodology to measure effectiveness of mediation systems.

160 See F. CAfaggi, in Judicial Cooperation, p 223, comparing remedies upon their function of, respectively, deterrence or compensation; O.O. Cherednychenko, ERPL 2015, p 487; F. Weber \& M. FAURe, 23. ERPL 2015, p 543; H.W. MickLitz, in The European Unfair Commercial Practices Directive, p 177 seq.; D. Poelzig, in The European Unfair Commercial Practices Directive, pp 10 seq.

161 See F. Cafaggi, 'The Great Transformation', LCLRev. 2009, p 517 seq.

162 See F. Cafaggr, in Judicial Cooperation, p 223. 
protection (Art. 47 CFREU), ${ }^{163}$ and, within criminal law, specific principles like proportionality of sanctions (Arts 49 and 50 CFREU).

We therefore contend that not only the triad should be applied within but also between enforcement mechanisms. Coordination should maximize effectiveness and dissuade from breaching the law but cannot result into disproportionate sanctions that would overdeter infringers and impose on them too high costs compared with consumers' benefits. ${ }^{164}$ Coordination should consider both the (1) structural dimension, e.g. which enforcer should have temporal priority and what kind of sequencing should occur, and (2) the functional dimension, e.g. which combination between sanctions and remedies ensures effective judicial protection.

\subsection{The Structural Dimension}

46. The main issue is whether coordination should imply sequentiality or enforcement mechanisms could operate simultaneously. In the former case how should the sequence be designed ${ }^{165}$ ? Sequentiality is generally regulated by law and it imposes one enforcer to stay the proceeding until the other enforcer has issued a final decision, which may or may not have binding force. ${ }^{166}$ In some areas like competition law, decisions of the first enforcer (e.g. the European Commission) are binding on national courts and now, with the Antitrust Damages Directive, this is true also for sanctions issued by national authorities ${ }^{167}$; in other areas of consumer law courts are not legally bound by the decision and, in theory, they can qualify as infringement a conduct considered lawful by an administrative enforcer. ${ }^{168}$ Sequentiality seems to fit better with the principle of proportionality and, possibly, with dissuasiveness.

47. Once the choice of sequentiality is made, should the principles of effectiveness, proportionality and dissuasiveness contribute to define the type of sequence, e.g. which enforcer should act first? Should a negative or positive decision by one enforcer concerning the existence and seriousness of an infringement influence the

163 See CJEU 21 December 2016, C-119/15, para. 47.

164 D. Poelzig, in The European Unfair Commercial Practices Directive, p 257 seq.

165 For an example in which lack of coordination in sequentiality between judicial and administrative enforcement has impaired effectiveness see V. BALOGH \& K. J. CsEREs, 36. JCP 2013, p 362.

166 See for example the Italian Art.140-bis(6) of the Consumer Code permitting the court to stay proceeding until the administrative authority has issued a final decision.

167 See Art. 9 Dir. 2014/104.

168 See e.g. Italian Corte di cassazione, Joint Chambers, 15 January 2009, no. 794, establishing that the ascertainment of a misleading practice by the Competition Authority may provide useful but not conclusive elements for a court ascertaining the occurrence of 'unjust damages' ('danno ingiusto'). 
proceedings in the other enforcement mechanisms? Should sanctions and remedies in the proceedings that follow consider the decisions of the former enforcer? Should the principles define what evidence can be used in the proceedings following the first one? We posit that the principles should play a role. All the answers to these questions should be given by MS legislation taking the principles into account when implementing EU law. ${ }^{169}$

The principles can provide guidance on how to structure a sequence of enforcement mechanisms that is at the same time dissuasive, effective, and proportionate. But, even more importantly, they can contribute to define the relative weight of enforcement mechanisms. Especially when the functions are similar, it might be more effective to pursue deterrence with administrative rather than the criminal enforcement mechanisms, taking into account proportionality. ${ }^{170}$ Hence, for example, proportionality of sanctions may call for a limited use of criminal enforcement and a wider use of combined civil and administrative enforcement. ${ }^{171}$ Differences may concern the relationship between collective redress pursued via administrative or judicial private enforcement and individual responsibilities addressed by the criminal system. Effectiveness and dissuasiveness may contribute to find the right balance. The principles should contribute to complement collective and individual redress. The complementarity between them can result into the adoption of collective redress when effectiveness and dissuasiveness would not be achieved in individual small claims. ${ }^{172}$ Claims' aggregation resulting in collective remedies, including pecuniary and non-pecuniary, can warrant effectiveness and dissuasiveness harder to achieve which via multiple individual claims especially when they are homogeneous.

48. When applying the principles courts should define the sanctions by considering those already administered by the previous enforcer(s). Clearly coordination is easier when enforcement mechanisms operate ex officio as it is the case for criminal and administrative. In this instance there should be no uncertainty over the coming into effect of both enforcement mechanisms, even taking into account the ne bis in idem principle. When the criminal judges evaluate the crime, they can internalize what has already been decided by the administrative enforcer and vice versa. Hence the choice between restitution of profits may be influenced by

169 See F. Cafaggi \& H.W. Micklitz (eds), New Frontiers, p 653.

170 On the theoretical relationship between administrative and civil enforcement see F. WEBER \& M. FAURE, 23. ERPL 2015, p 525, revisiting the conventional law and economics perspective defined by A. Mitchell Polinsky \& Steven Shavell, 'An Economic Theory of Public Enforcement of Law', 38. JEL (Journal of Economic Literature), p 45. See for an analytical framework F. CAFAGGI, 'The Great Transformation', LCLRev 2009, p 496.

171 However, given the higher degree of procedural rights granted to criminal defendants, the infringer might not always be better off in administrative enforcement.

172 See F. Cafaggi \& H.W. Micklitz (eds), New Frontiers, p 653. 
the nature of the injunction or even the amount of the fine ordered by the administrative authority.

Coordination is less easy when enforcement is possible but there is uncertainty about whether it will occur as it is mostly the case for private judicial enforcement combined with administrative. In civil judicial enforcement, the decision is in the hands of the individual consumer or on the consumers' organization. The well-known distinction between follow on and stand alone proceeding suggests that different types of coordination may be required and priority over one type of enforcement may lead to different results. To discount in the criminal or administrative proceedings what will later happen in the civil proceedings is impossible, since there is no certainty that parties will ever go before a judge to seek a civil remedy influencing the choice of administrative or criminal measures. In this instance coordination may require the court dealing with private enforcement to internalize criminal and/or administrative sanctions according to the principles of effectiveness, proportionality and dissuasiveness. Hence, temporal priority should be given to administrative enforcement. Within this framework both enforcers will be required to refer to the principles but the latter would have to take into account what the former did. When deciding on whether and what kind of injunction should be ordered or what kind of restitutionary measure should be crafted, the court may be required to consider whether the infringer has already been sanctioned by another enforcer, criminal or administrative, and define the content and effect of the injunction or restitution accordingly. Here proportionality will not be linked to the ne bis idem but to other criteria like the deterrence or compensatory function of consumer protection. Both functional and procedural considerations should be made.

49. Differences among enforcement mechanisms can lead to combination of sanctions and remedies to pursue the same objectives (deterrence) or different objectives (deterrence and compensation). As mentioned, the principle of legality has different impact on enforcers' discretion and may lead to more innovative remedies in civil courts than in criminal courts or in administrative bodies. Looking at practices in MS, the differences are better explained by judicial cultures rather than by the black letter rules.

\subsection{The Functional Dimension}

50. The triad has not been so far explicitly used in national legislation to coordinate sanctioning across enforcement mechanisms. Neither the EU legislator nor national ones offer specific guidance on how the principles should be applied when multiple enforcers are in action for the same infringement. Conventionally the enforcement regimes have been associated with single functions: private enforcement with compensation, administrative enforcement with deterrence, criminal enforcement with punishment. As it was repeatedly pointed 
out, this bright line has blurred and, for example, administrative enforcement is now playing multiple functions. ${ }^{173}$

51. Effectiveness can play a relevant role when two enforcement mechanisms are in place pursuing different concurring objectives, e.g. deterrence and compensation. It should therefore be warranted that injunctions in administrative enforcement are linked to damages in judicial enforcement by regulating procedural aspects related to evidence, avoiding the consumers to bear costly burdens of proof when unfair commercial practices or anticompetitive agreements have been concluded. A strong case to use the triad as guidance for legislative and jurisprudential coordination of sanctions and remedies also arises when different enforcement systems pursue identical or similar functions. When for example there is an issue of coordination between criminal and administrative measures both pursuing deterrence, a clear case emerges for the application of the principles to achieve deterrence within proportionality. As stated before the principles contribute to avoid the risk of both under- and over-deterrence. But the use of the principles of dissuasiveness and proportionality concerns also the relationship between administrative and private enforcement when, for example, both administrative and judicial injunctions are in principle possible.

52. Another area of potential interferences related to deterrence is that of noncompliance with injunctions. When the enterprise violating consumer's rights does not comply with the injunctions or with the commitments to change the unfair practice, courts can order the payment of a sum for each day of non-compliance (Art. 2 Dir. 2009/22). Similar astreintes can be used also by administrative courts or administrative enforcing authorities when there is no compliance with administrative sanctions including the payment of fines. ${ }^{174}$ Lack of cooperation by infringers against consumers can also trigger penalties (Art. 13 Dir. 2014/104). Coordination between administrative authorities and courts in ensuring compliance should lead to a determination of proportionate fines for non-compliance with sanctions. Hence proportionality of sanctions, for example the amount of an astreinte or a fine, should be evaluated across enforcement mechanisms unlike

173 This trend is likely to increase, given the power to order compensation and profit restitution that the new CPC regulation proposal includes among the minimum powers that national competent authorities should be given for cross border infringements of consumer law. See Proposal for a Regulation on cooperation between national authorities, Art. 18.3.

174 See e.g. under Italian consumer law, Art. 27(12) Cons. Code, assigning such power to the Competition Authority in case of violations of injunctions related with unfair commercial practices, and Art. 140(7) Cons. Code, assigning a similar power to the court providing for a measure of injunctive collective redress upon request of consumer associations. See also the decision of the Italian Consiglio di Stato 25 June 2014, no. 15, extending, in the light of the principle of effectiveness of judicial protection, the use of judicial astreintes to the case of breach of monetary obligations by the State. 
what happens under the current regimes, where the principles are applied to each regime and not across enforcement regimes.

53. A more difficult case is that of coordination with ADR. There should be little doubt that the principles ought to be applied when ADR are regulated by law and they interplay with other forms of enforcement as in the case for example of mandatory mediation. ${ }^{175}$ What if the ADR is not regulated by law but by selfregulatory arrangements, for example by a code or a by guidelines or recommendations? In advertising, for example, national self-regulatory organizations (SROs) ordinarily use among their sanctions orders to cease or desist from continuing to show a deceptive or misleading advertisement. ${ }^{176}$ The principles should also be applied by private actors, regulating enforcement protection of consumers. ${ }^{177}$

How is the interplay between administrative enforcement and ADR affected by the application of the principles? Should public enforcers take into account the decisions of SROs when deciding other types of sanctions to be combined with the injunctions? Does the private nature of the dispute resolution mechanism prevent the application of the principle of proportionality of sanctions or should it be considered by both administrative and judicial enforcers? If for example the private enforcer has already ordered to modify the commercial practice to ensure respect with fairness, should the public enforcer add an injunction or order the payment of a fine if the privately issued injunction has not been complied with? From a functional standpoint, no difference should be made dependent upon the public or private nature of the enforcer. From a formal perspective, clearly the application of the principles to a purely private regime presupposes horizontal application of the principles to private parties, which might be problematic for those legal

175 See e.g. the application of the principles of effectiveness and proportionality in the Alassini case (CJEU 18 March 2010, Joined Cases C-317/08, C-318/08, C-319/08 and C-320/08), which has triggered the development of dissenting case law on whether the lack of mandatory attempt of settlement should lead the court to stay the proceedings (Italian Corte di cassazione 4 December 2015, no. 24711) or to end it for inadmissibility (Tribunal of Milano, s. XI, of 24 September 2014 and 17 December 2015). See also N. ReIch, "A "Trojan Horse" in the Access to Justice - Party Autonomy and Consumer Arbitration in Conflict in the ADR-Directive 2013/11/EU?', 10. ERCL (European Contract Law Review) 2014(2), pp 258-280.

176 F. CAfaggi, The Enforcement of Transnational Regulation (Cheltenham: Elgar 2012); P. Verbruggen, Enforcing Transnational Private Regulation (Cheltenham: Elgar 2014), p. 300; F. Cafaggi, A Comparative Analysis of Transnational Private Regulation: Legitimacy, Quality, Effectiveness and Enforcement, EUI working paper 2014/15, available at http://cadmus.eui.eu/ bitstream/handle/1814/33591/LAW_2014_15.pdf.

177 See on the issue of horizontal application A. Hartkamp, European Law, p 13 seq; F. Mezzanotte (ed.), Le 'libertà fondamentali' dell'Unione europea e il diritto privato (Rome: Roma-Tre Press 2016), part. A. Zoppini, 'Il diritto privato e le 'libertà fondamentali' dell'Unione europea (Principî e problemi della Drittwirkung nel mercato unico)', ibid., p 9 seq.; F. Cafaggi \& P. Iamiceli, 'The Principles of Effectiveness, Proportionality and Dissuasiveness in EU ADR', on file with the authors. 
systems that only recognize vertical application of the principles (i.e. to legislation). ${ }^{178}$

54. The principles contribute to defining coordination among various enforcement mechanisms in place. Effectiveness, proportionality, and dissuasiveness should be evaluated taking into account the interaction and, in relation to sanctions, the cumulative effects of sanctions and remedies.

\section{Concluding Remarks and Pending Issues}

55. The erosion of the principle of procedural autonomy is reallocating powers between European institutions and MS to identifying the appropriate remedies and to defining their content and objectives. National legislations must design sanctions and remedies compliant with the principles of effectiveness, proportionality and dissuasiveness. When the legislation leaves judge's discretion over the choice among remedies or the intensity of the specific remedies (the content of the injunction, e.g. suspension of the activity, engagement in corrective action, the amount of the fine, the relationship between pecuniary and non-pecuniary remedies), the principles should provide guidance to courts in making decisions. Absent clear legislative guidance, the CJEU should provide guidance to national courts on how to apply the principles and how to solve potential conflicts among them.

56. The principles operate across a wide range of policy areas and national legislations are not always consistent when translating them into sanctioning policies. By definition, principles allow some degree of flexibility serving the objective of adaptation to the specific goals of legislation. Hence, it is admissible and even desirable that proportionality of sanctions in asylum or migration may lead to different results from proportionality in financial market violations for market abuse or in consumer for unfair commercial practices. Often proportionality has been used to balance different and sometimes conflicting interests like those of consumers and professionals. Furthermore, it is possible that the potential trade-offs between the principles may lead to different results: in some areas dissuasiveness may prevail over proportionality, in other areas the opposite may be true. ${ }^{179}$ However, differences should be made explicit and justified in respect of the default, this being a uniform definition of the principles.

178 A. HartKamp, European Law, p 17. See, however, in the EU case-law, CJEU 12 July 2012, Fra.Bo $\operatorname{SpA}, \mathrm{C}-171 / 11$, on the application of EU principles to standardization and certification activities of a private-law body.

179 See e.g. CJEU 9 November 2016, C-42/15, and the Opinion of Advocate General Sharpston delivered on 9 June 2016 in the same case, part. paras 67 seq., for a comparative assessment between effectiveness, dissuasiveness and proportionality. 
57. Both remedies and sanctions applied at the national level must comply with the principles of effectiveness, proportionality and dissuasiveness. The principles have an impact at least on three dimensions: (1) the content of the single remedy, (2) the combination between different remedies within the same enforcement mechanism, (3) the coordination between enforcement mechanisms. Their contextual application may force to balance them since they may protect different or even conflicting interests, those of the injurers and the consumers but also those of third parties. The clearest example is the potential conflict between dissuasiveness and proportionality. This conflict may arise in relation to the content of a specific remedy, for example the amount of an administrative fine, or between two remedies within the same enforcement mechanism, for example the choice or the combination between a fine and an injunction, or between enforcement mechanisms like criminal and administrative when ne bis in idem does not apply.

58. Clearly whether the focus is on the infringer (sanctioning) or on the injured (remedies) might change the perspective and the objectives of the principles' application. In both instances the other party's interests must be taken into account. Hence, when deciding about the deterrence effect of sanctions, the position of the potentially injured party should be considered as to the consequences of the violation e.g. whether it will only affect a small group or a large group of individuals will certainly contribute to determine both the type and the intensity of sanctions. Similarly, whether only economic or also health and dignity of the consumers are affected by the violations influences the definition of the sanctions. Symmetrically, the position of the injurer is relevant when defining the remedy, including the size and the market share of the infringer(s). This is not the case in the current case law. For example, in consumer's sales the proportionality between repair and replacement or between repair and termination is determined partly regarding the importance of the non-conformity and the costs incurred by the seller to provide the buyer with an effective remedy whereas no significant relevance is given to the size of the injurer, which may be a real issue if the harm is collective rather than individual.

The simultaneous application of the principles may lead to balancing the rights of the undertakings and those of consumers as the potential conflict between effectiveness and proportionality shows. Often the legislation does not clarify whether one or multiple principles should be applied and courts in various MS have chosen different principles to regulate substantive and procedural matters as the example of burden of proof and creation of judicial presumptions shows.

59. The illustrations in the text suggest that references to the principles in national judicial applications are not extensive and that their definition is not consolidated. It is likely that judicial dialogue between CJEU and national courts will shape the applications of the principles. Institutional dialogue between courts and administrative enforcers will also play an important role to ensure that 
legislative choices are compliant with EU objectives and to fill gaps when legislators or regulators omit to offer proper guidance to national judges.

Effectiveness of consumer enforcement is far from being satisfactory and the principles' application will improve the quality of consumer protection only if supported by adequate instruments of coordination among enforcement mechanisms and within each enforcement regime. 